\title{
Medievalista
}

Online

4 | 2007

Número 4

\section{Mosteiro de Santa Maria das Júnias}

\section{Delmira Espada}

\section{OpenEdition}

\section{Journals}

\section{Edicão electrónica}

URL: http://journals.openedition.org/medievalista/4398

DOI: $10.4000 /$ medievalista.4398

ISSN: 1646-740X

\section{Editora}

Instituto de Estudos Medievais - FCSH-UNL

\section{Refêrencia eletrónica}

Delmira Espada, «Mosteiro de Santa Maria das Júnias», Medievalista [Online], 4 | 2007, posto online no dia 05 março 2021, consultado o 24 março 2021. URL: http://journals.openedition.org/medievalista/ 4398 ; DOI: https://doi.org/10.4000/medievalista.4398

Este documento foi criado de forma automática no dia 24 março 2021.

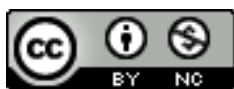

Mediavalista está licenciado com uma Licença Creative Commons - Atribuição-NãoComercial 4.0 Internacional. 


\title{
Mosteiro de Santa Maria das Júnias
}

\author{
Delmira Espada
}

\section{NOTA DO AUTOR}

Fotografias da autora

\section{1. O MOSTEIRO NA PAISAGEM}

2 O Mosteiro de Santa Maria das Júnias encontra-se localizado num vale que fica a dois quilómetros a Sul da aldeia de Pitões das Júnias, na província de Trás-os-Montes. Pertence ao distrito de Vila Real, concelho de Montalegre, freguesia de Pitões das Júnias e localiza-se num vale estreito, de difícil acesso, isolado numa região fronteiriça.

3 Pitões das Júnias, situada na zona intermédia do Gerês e do Barroso, é uma pequena aldeia comunitária onde se sente que o tempo corre mais devagar. As suas gentes vivem em harmonia com a natureza, tirando dela todo o seu sustento. Com as suas casas sempre abertas para quem chega, aceitam de bom grado o bom e o mau que a natureza lhes oferece. Das terras bem tratadas retiram o centeio, da pastorícia o restante. 0 forno comunitário coze para toda a aldeia as grandes broas do centeio extraído das terras circundantes. As casas de granito desenvolveram-se de forma orgânica, adaptando-se às condições naturais do terrenoi. As ruas, estreitas e sinuosas, estão marcadas pelo vai e vem diário do gado bovino.

$\mathrm{O}$ acesso ao mosteiro é feito de carro até determinada altura fazendo-se o resto do percurso a pé, por um caminho irregular de lajes de pedra que nos conduz até ao vale da Serra da Mourela, entre os penedos do Ceres e de Larouco. 

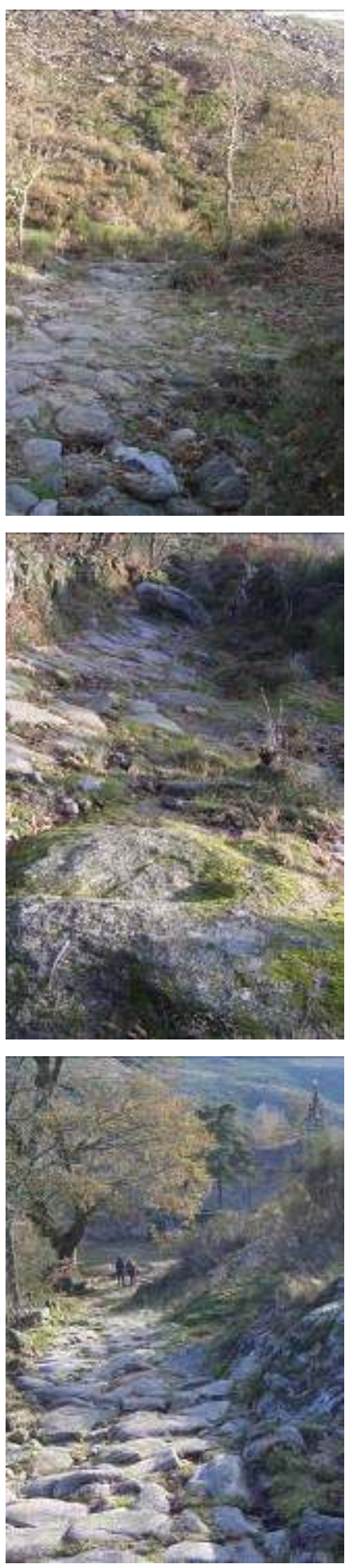

o caminho que dá acesso ao vale.

5 Aí chegados, deparamo-nos com o muro do cemitério que isola toda a fachada Norte da Igreja. Para se desfrutar de uma vista geral do mosteiro é necessário subir as encostas das serras que ficam de um lado e do outro da ribeira Campesinho. Subindo a encosta da serra a nascente, vê-se a fachada posterior da igreja, com o muro do cemitério à direita e, à esquerda, a ala dos monges, que se desenvolve ao longo da ribeira. Ao subir a 
encosta poente tem-se uma vista panorâmica que permite ver a fachada principal da igreja, a fachada Sul, o claustro e todo o complexo monástico.
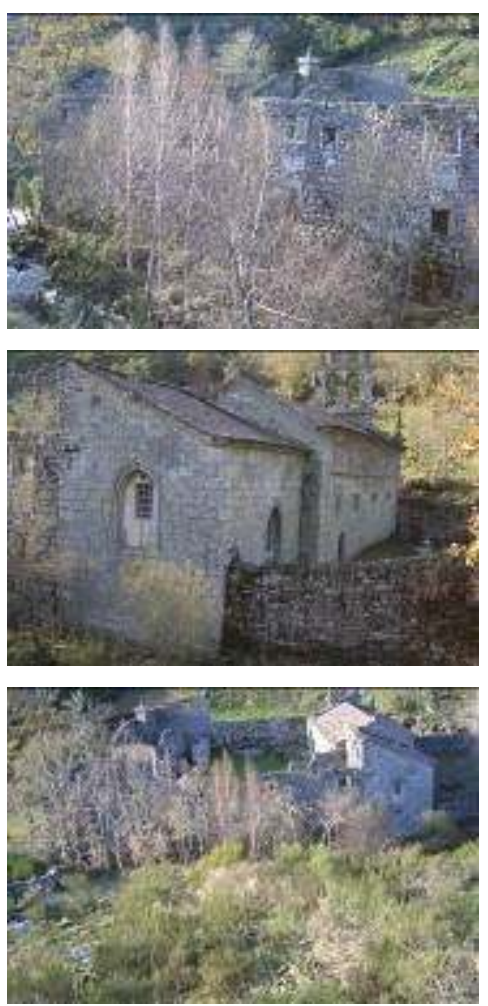

O mosteiro visto de nascente

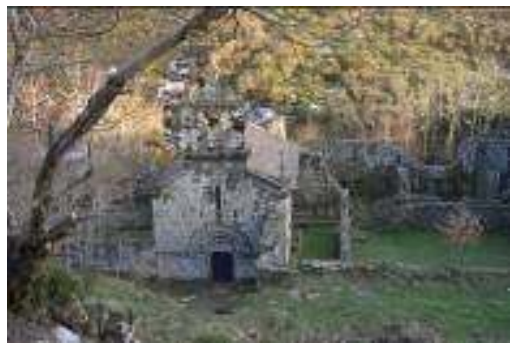

O mosteiro visto de poente
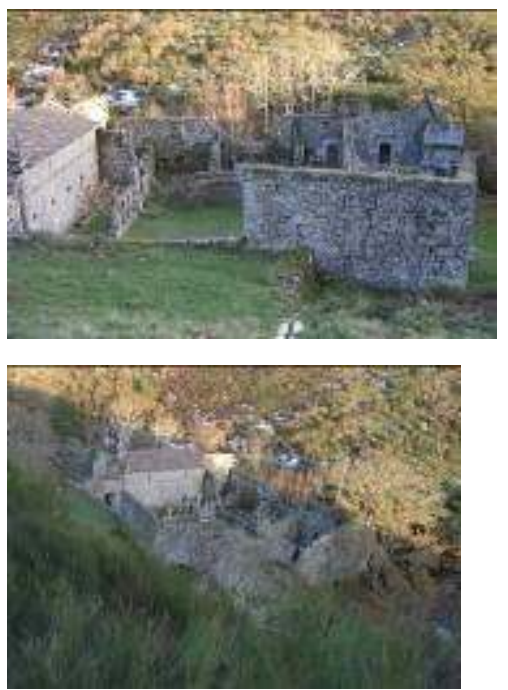

O mosteiro visto de Sudoeste 
Segundo um documento existente no cartório bracarense, o mosteiro de Santa Maria das Júnias, remonta aos finais do século IX, tendo sido inicialmente apenas um pequeno ermitérioii. São vários os autores que subscrevem esta afirmação, tendo por base as afirmações de Fr. Leão de São Tomás, na Benedictina Lusitana onde é referido o documento que testemunha a existência de Júnias desde 889. Mário Barroca reforça o facto deste documento apenas ter sido visto por Fr. Leão Tomás, acrescentando ainda: "não há qualquer testemunho seguro - documental ou arquitectónico - que permita fazer recuar as origens de Santa Maria das Júnias até uma época tão antiga. Pelo contrário, todos os elementos disponíveis, apesar de relativamente escassos, apontam para uma fundação dos finais da primeira metade do século XII, em torno do ano de 1147." iii Considero no entanto, que apesar da ausência comprovada de documentos escritos, possamos estar em condições de equacionar uma existência mais remota do edifício, com base na sua métrica e na evidência de uma presença romana no local, indiciada pela existência de uma ara em granito com inscrições, proveniente de Pitões das Júniasiv ${ }^{i v}$ Para além disso, e de acordo com informações da Direcção-Geral dos Edifícios e Monumentos Nacionais existe no Tombo do Mosteiro de Celanova (Galiza) um documento datado de 953, que regista a doação de propriedades em Travassos e outro documento datado de 1100 que regista doações feitas ao mosteiro.

8 Na fachada Norte da Igreja está gravada a data 1147, que é unanimemente apontada pelos vários autores ${ }^{v}$ como a data da fundação ou da sagração da igreja. De acordo com o Guia de Portugal da Gulbenkian, 1147 é também a data em que o bispo do Porto, Pedro Pitões (ou Pedro de Pitões) recebeu os cruzados nórdicos e os convenceu a lutar ao lado de D. Afonso Henriques na conquista da cidade de Lisboa. Esta coincidência temporal pode ser relevante na procura do significado da presença desta data na fachada Norte da igreja. Nesta data, os monges seguiriam a regra beneditina. Relativamente à sua passagem para a Ordem de Cister, só em 1248 é que se conhecem documentos que o comprovem, através de uma bula do papa Inocêncio IV, Benigvolum et Benignum, datada de 2 de Junho onde este declara ao arcebispo de Braga, D. João Egas, não se opor à inscrição do mosteiro de Júnias na Ordem de Cistervi. A 21 de Novembro do mesmo ano, no decreto arquiepiscopal de execução da Bula papal, D. João Egas autoriza a passagem do mosteiro para a regra de Cister, impondo algumas contrapartidas compensatórias. "O Mosteiro entrega o couto de São Pedro de Vilaça e dois casais em troca da terça das mortuárias e outros direitos que o Arcediago de Barroso recebia do mosteiro e da Capela do Gerês, e que a partir de então deixaria de receber."vii Existe ainda um segundo documento, datado do mesmo dia, no qual o Abade de Santa Maria das Júnias, D. João, declara aceitar as condições impostas pelo arcebispo, D. João Egas. Nas inquirições régias de D. Afonso III, em 1258, é referida uma doação de D. Afonso Henriques ao mosteiro e em 1271 o mosteiro recebe 100 libras deixadas em testamento por D. Afonso III ${ }^{\text {viii }}$

Quanto à filiação, o mosteiro esteve ligado, em períodos alternados, ao mosteiro de Oseira (Galiza) e ao mosteiro de Santa Maria do Bouro. No início da Guerra da Restauração, a população de Pitões da Júnias expulsou o abade do mosteiro por este ser galego, tendo mesmo recusado a nomeação de outro pelo mosteiro de Oseira. A situação acabou por se resolver através da nomeação de um abade pelo mosteiro do Bouro.

$\mathrm{O}$ mosteiro acabou por entrar em decadência, nos finais do século XV, depois da morte do abade Dom Gonçalo Coelho, tendo sido abandonado por volta de 1520, ano em que o comendatário Estêvão da Costa, clérigo secular, tomou a seu cargo o governo da Igreja 
de Júnias. Dom Gonçalo Coelho foi abade de Santa Maria das Júnias entre 1499 e 1501. Natural de Chaves e monge do mosteiro beneditino de Santo Tirso, foi nomeado abade de Santa Maria das Júnias em 1499. Desempenhava funções em Pitões e em Cela, na Galiza. Percorria cerca de doze quilómetros para se deslocar a Celas. Viria a falecer numa dessas deslocações, tendo sido encontrado gelado, ajoelhado em sinal de oração, com os olhos virados para o céu e os braços abertos, no dia 2 de Fevereiro de 1501. Foi venerado como santo até finais do século XIX.

11 Nos dias 27 e 28 de Janeiro de 1533 o Mosteiro foi visitado por D. Edme de Saulieu, abade de Claraval. Segundo os relatos de Bronseval, que o acompanhou, à excepção da igreja, as dependências monásticas encontravam-se em ruínas e despojadas de monges. Em 1566 é retomada a vida monástica, passando a ter como abade regular Dom Valeriano de Villada. É durante o século XVI que se faz a abertura da fresta e o alteamento da fachada principal. Por não estar incluído nas tábuas da Congregação de Alcobaça, pensa-se que terá ficado afecta ao mosteiro de Oseira que, depois de 1567, reclama para si os direitos sobre Santa Maria das Júnias ${ }^{\mathrm{i}}$.

Durante a Guerra da Sucessão espanhola o Mosteiro de Oseira volta a invocar direitos sobre Santa Maria das Júnias. Apesar de haver documentos que nos informam sobre as várias campanhas de reforma entre 1726 e $1728^{\mathrm{x}}$, o mosteiro, segundo nos informa o visitador de Oseira encontrava-se em grande decadência, acabando mesmo por se extinguir em 1834/5, tendo como último monge Frei Benito Gonçalves.

14 De todo o conjunto monástico, a igreja é a única que está conservada. É uma igreja de nave única longitudinal, com cobertura de madeira e telhado de duas águas. A capelamor, adjacente à fachada posterior da igreja é virada para Este. Tem planta rectangular ${ }^{x i}$ e é coberta por um telhado de uma só água com pendor Sul - Norte.

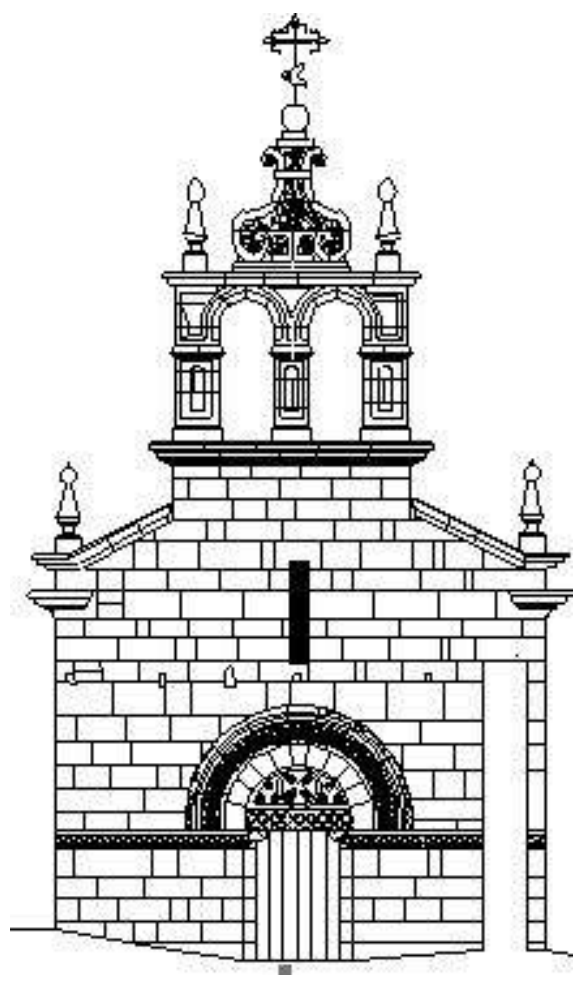

Levantamento arquitectónico do Alçado Poente, segundo José Custódio 
16 A fachada principal, virada para Poente, é delimitada pelo muro do cemitério à esquerda e pela cerca do mosteiro, com a respectiva porta de entrada, à direita. É uma fachada simétrica, de grande simplicidade, rematada por empena de cornija moldurada, truncada por um campanário frontão de dupla ventana, coroado por uma cruz metálica com cata-vento e por dois pináculos. Sobre os cunhais da empena encontramos outros dois pináculos, muito semelhantes aos anteriores. Por cima do portal há uma fresta perspectivada igual às que se encontram nas fachadas laterais. Ao longo de toda a fachada, entre o portal e a fresta, à altura do muro da cerca, encontram-se seis buracos, possivelmente de uma antiga galilé, solução equivalente ao "antigo nartex das basílicas visigóticas e cujo destino primordial parece ter sido o funerário."xii A abertura da fresta e a alteração da fachada, para introdução do campanário, são obras do século XVI.

O portal em arco perfeito peraltado, praticamente sem perspectiva, revela grande harmonia e singularidade. Tem duas arquivoltas estruturais e uma terceira ornamental que só aparece na fiada da alvenaria exterior. Uma interna, de arestas vivas sem decoração, outra externa ornada com um friso lanceolado com orla inferior lisa e a terceira com triplo toreado, sendo o último ornado com o tema das fitas listadas dobradas. As arquivoltas assentam sobre a imposta que se estende sobre toda a fachada. É ornada, em relevo fundo, com corações invertidos simples, unidos por presilha e orla superior lisa. o tímpano é vazado formando uma composição simétrica. Ao centro uma cruz vazada, circunscrita por duas circunferências concêntricas gravadas na pedra. De ambos os lados da cruz estão três perfurações circulares dispostas de maneira a formar um triângulo de cada ladoxiii. Uma linha, gravada na pedra, delimita uma margem regular no tímpano que é tangente aos seis orifícios vazados. o lintel, sobre o qual se apoia o tímpano, é ornado com bandas de quadrifólios gravados na pedra, ou seja, motivos geométricos resultantes da intersecção de circunferências - a mesma construção geométrica que serve de base à construção da cruz vazada no tímpano. De salientar ainda que é visível sobre a pedra do lintel, um ponto gravado que é o centro da composição do portal. As mísulas que apoiam o lintel também têm motivos geométricos gravados: contudo não se encontra para estas uma ordem clara. A mísula do lado esquerdo apresenta alguns registos semelhantes aos do lintel: no entanto não se pode tratar da mesma decoração uma vez que são visíveis duas formas folhiformes paralelas. 
Na mísula da direita são visíveis pequenos círculos gravados. A sua pouca visibilidade e organização não permitem encontrar uma lógica construtiva.

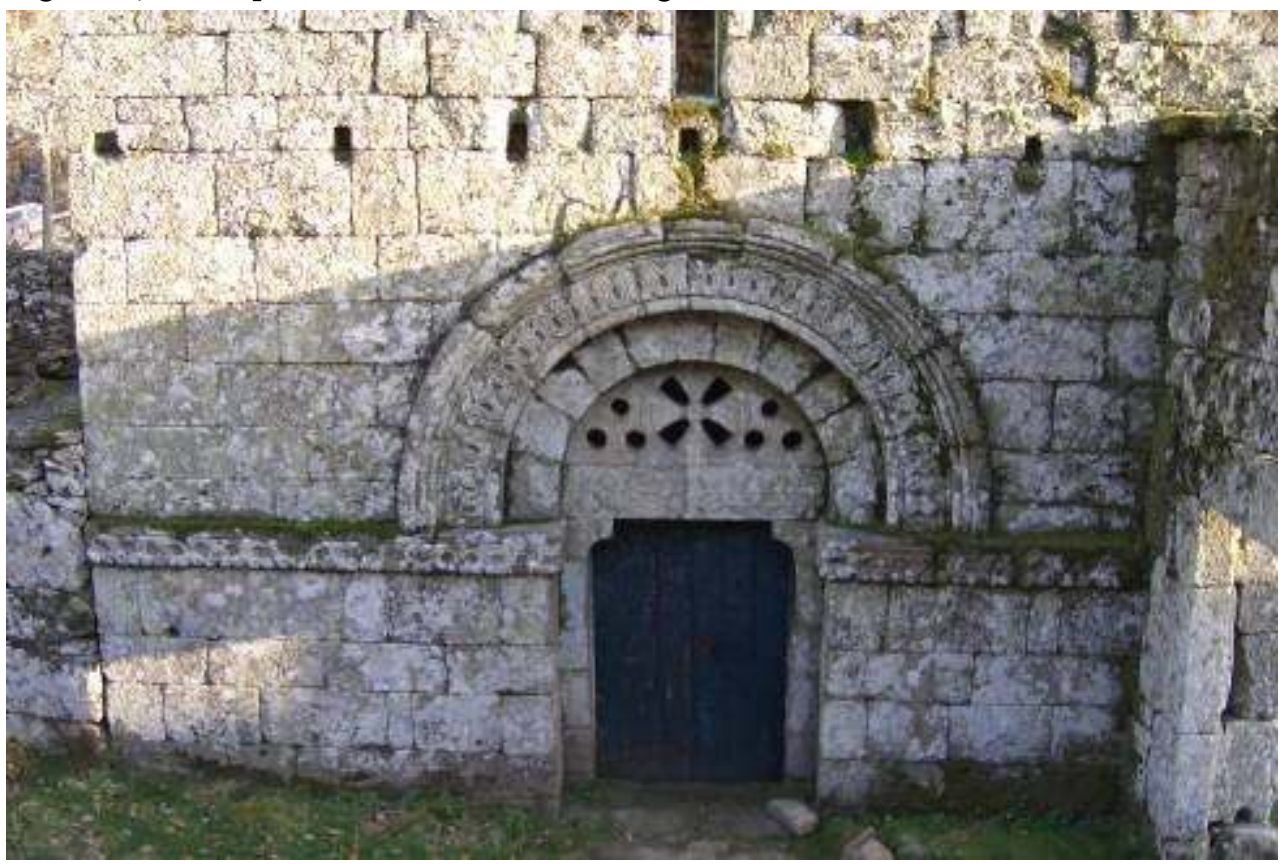

Portal principal

\subsubsection{A gramática ornamental do portal}

A gramática ornamental do portal enquadra-se no românico tardio da região norte do país. São muitos os exemplos onde encontramos os temas representados em Santa Maria das Júnias: no entanto não há nenhum edifício que se possa equiparar a esta singular igreja, pelo equilíbrio e sobriedade que apresenta. Se nos centrarmos apenas na sua gramática ornamental, são muitos os exemplos que podemos citar. De facto, os motivos cordiformes, as fitas dobradas e as pontas de lança, são elementos recorrentes do nosso românico. Podemos encontrá-los nas Igrejas de Manhente (Concelho de Barcelos), Ferreira (Concelho de Paços de Ferreira), Arnoso (Concelho de Vila Nova de Famalicão), entre outras, só para citar os casos em que estes elementos se combinam no portal. No entanto, qualquer dos portais citados é, não só mais perspectivado, como apresenta também colunas, o que em Santa Maria das Júnias não acontece.

Se atendermos às características do tímpano, podemos citar vários exemplos onde os tímpanos apresentam uma cruz vazada: Igreja de Unhão (Felgueiras), São Pedro das Águias(Tabuaço), Arnoso (Famalicão), Sé de Braga (porta do sol), todos eles próximos entre si, mas mais uma vez distantes do que acontece em Santa Maria das Júnias. Qualquer destes tímpanos, embora vazados, apresentam cruzes muito trabalhadas, geralmente ladeadas por motivos enlaçados ou por animais afrontados ${ }^{\mathrm{xiv}}$. $\mathrm{O}$ que mais se aproxima de Santa Maria das Júnias é o tímpano da porta Sul da Igreja de Arnoso (sendo o do portal principal mais próximo dos anteriormente citados).

Pela sua contenção ornamental e pela ausência de profundidade, que se viria a acentuar progressivamente, como nos mostram os muitos exemplos do românico português, podemos ser levados a pensar que Pitões das Júnias remonta a uma época mais recuada, em especial se tivermos em consideração as informações da Direcção Geral dos Edifícios e Monumentos Nacionais, que nos dão conta da existência de dois documentos no 
Tombo do Mosteiro de Celanova, referentes a Santa Maria das Júnias e datados de 953 e 1100. celeste, é passível de muitas leituras. Se olharmos para o tímpano com um olhar menos codificado, mais inocente, até pelo confronto com a decoração do lintel, a primeira leitura que se faz, não é a cruz branca de pedra, mas o espaço negativo que o vazado deixou; um jogo geométrico que remete para uma temática vegetalista. No interior escuro da igreja esta leitura é ainda mais acentuada; no lugar da cruz surge uma estrela que guia e o tímpano transforma-se numa abobada estrelada. No portal de Santa Maria de Júnias esta leitura assume um significado ainda maior, uma vez que estão representadas sete estrelas. 0 número sete presta-se a muitas leituras: os sete dias da criação, o tempo presente que se desenvolve em ciclos de sete dias, mas também as sete igrejas do apocalipse, simbolizadas por sete candelabros e por sete estrelas. Sem esquecer que a construção geométrica da cruz, é feita a partir da intersecção de sete circunferências. Se é verdade que, durante o dia, no escuro do interior da igreja, a luz que entra pelos vazados nos mostra um céu estrelado, a inversa também será verdadeira. Durante a noite, naquele vale isolado, estando a igreja iluminada, projecta para o exterior a mesma imagem, que durante o dia se tem no seu interior. Se pensarmos, que Santa Maria das Júnias ficava num dos caminhos de Santiago e que uma das suas funções era o albergue de peregrinos, estes tímpanos vazados ganham ainda uma importância maior, funcionando como verdadeiras estrelas que conduzem os peregrinos. Sabendo que as frestas, pelo menos a do alçado principal, só foram acrescentadas no século XVI, os únicos pontos de luz, com excepção da cabeceira, eram as aberturas dos tímpanos.

Fazendo o esforço por me colocar numa perspectiva diferente, procurando uma leitura comparada deste tímpano com os exemplos do românico anteriormente citados, poderia aceitar como válida a possibilidade de ter sido exactamente esta dificuldade de legibilidade que levou os cantoneiros a acentuar a decoração dos tímpanos. No entanto, essa perspectiva colocaria a execução do portal de Santa Maria das Júnias num contexto em que eu não o enquadro. A lógica construtiva pela qual o edifício é regido, a forma como se estrutura e os significados que carrega, não comportam, em meu entender, uma intenção falhada. Também não vejo neste portal, "um reflexo dos escassos meios económicos disponíveis e de uma certa ingenuidade do artista responsável pela obra", como entendeu Mário Barroca ${ }^{\mathrm{xv}}$. Pelo contrário, vejo uma opção estética racionalmente construída com motivos que remontam ao visigótico

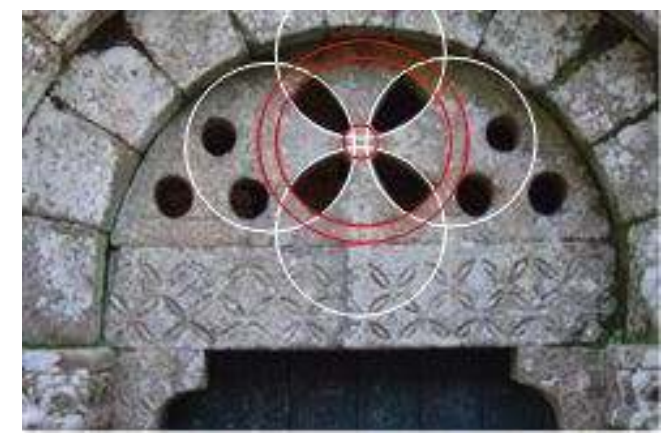

Construção geométrica da cruz do tímpano 


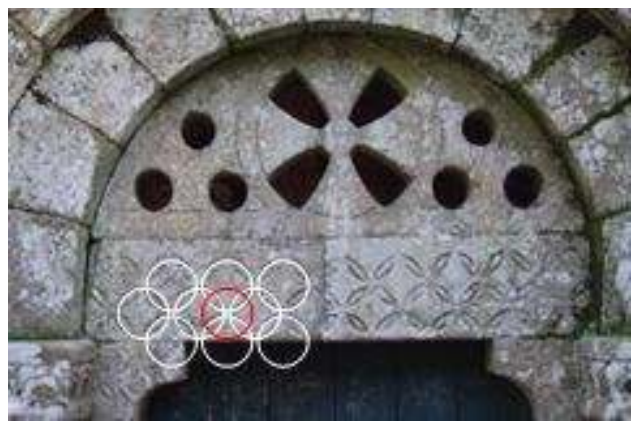

Construção geométrica da ornamentação do lintel

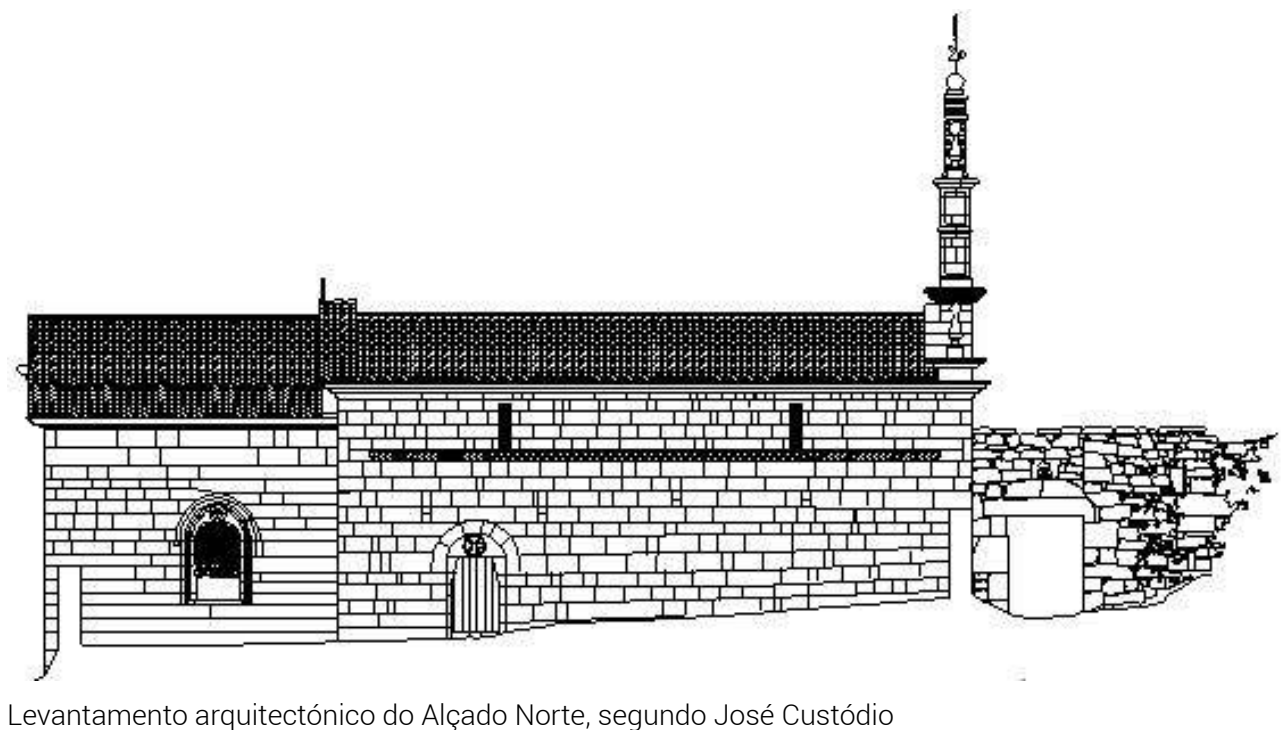

O muro do cemitério isola toda a fachada Norte, incluindo a cabeceira, delimitando uma área relativamente grande em forma de trapézio. 0 portão de ferro do cemitério, paralelo à fachada da igreja, adaptou-se ao grande portão de arco de volta inteira do muro, ${ }^{\text {vi }}$ negando-nos a aproximação ao edifício. Do alto do muro, sobre o portão, recebem-nos dois animais fantásticos, em escultura de vulto, eventualmente com valor apotropaico, que lembram pelo porte o gado barrosão. Entre as figuras destes animais vê-se ainda a base onde assentaria uma terceira figura.

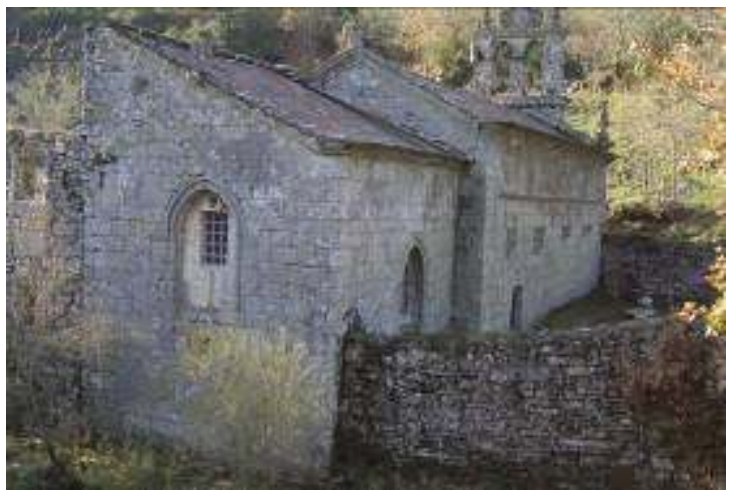

Fachada Norte vista de noroeste 


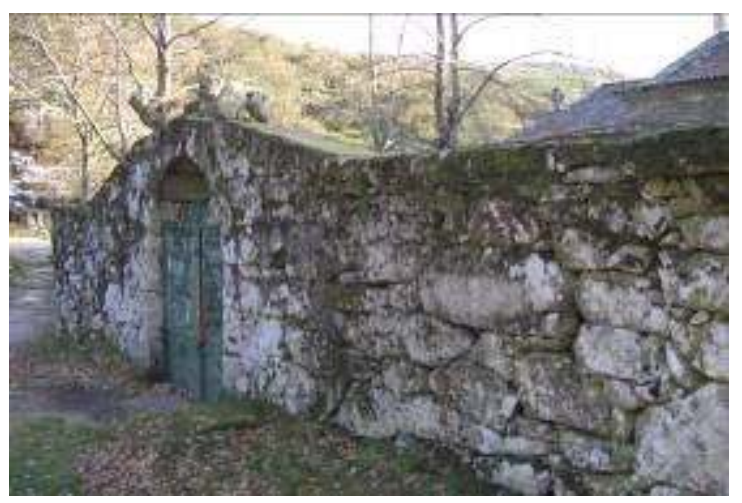

Muro do cemitério

26 A fachada lateral Norte, cercada pelo cemitério, é lisa, simples e sem perspectiva. Rematada superiormente por cornija molduradaxvii é percorrida por um friso ornado que não chega aos extremos da fachada. A decoração geométrica do friso não é constante; começa e termina com um enxaquetado de quadrados esquinados sobrepostos em duas filas, mas na zona central, entre as duas frestas, o padrão altera-se surgindo duas linhas em zig-zag paralelas. Todo o friso é acompanhado por uma orla superior lisa.

Sobre o friso abrem-se duas frestas rectangulares estreitas e perspectivadas, iguais às da fachada lateral sul e à da fachada principal. Duas fiadas abaixo do friso distribuemse ao longo da fachada cinco mísulas, que terão servido provavelmente de suporte a uma estrutura de madeira. Quanto à sua decoração, fazendo a leitura da esquerda para a direita, ou seja, da cabeceira para a fachada principal temos: a primeira, encontra-se danificada e sem decoração; a segunda é decorada com uma esfera solta em alto-relevo; a terceira apresenta uma decoração geométrica em relevo de rectângulos sobrepostos; a quarta é semelhante à segunda apresentando duas esferas em vez de uma; e a quinta semelhante à terceira, com a diferença que enquanto na terceira temos três rectângulos sobrepostos na quinta temos apenas dois. De salientar ainda que as duas primeiras mísulas, que ladeiam a porta, aparecem não na segunda fiada mas na terceira a contar do friso para baixo, tendo sido alteadas para ficarem à mesma altura das restantes.

A porta, como já se disse, fica situada entre a primeira e a segunda mísula. É de arco pleno peraltado, sem perspectiva, tendo como único ornamento uma cruz vazada no tímpano, igual à do portal principal, realçada por uma coroa circular gravada na pedra. o lintel, assente em impostas lisas, foi cortado para altear o vão da porta. Segundo Mário Barroca, as impostas, teriam sido originalmente iguais às do portal principal, tendo sido desbastadas para se adaptarem à nova situação ${ }^{\text {xviii }}$. 


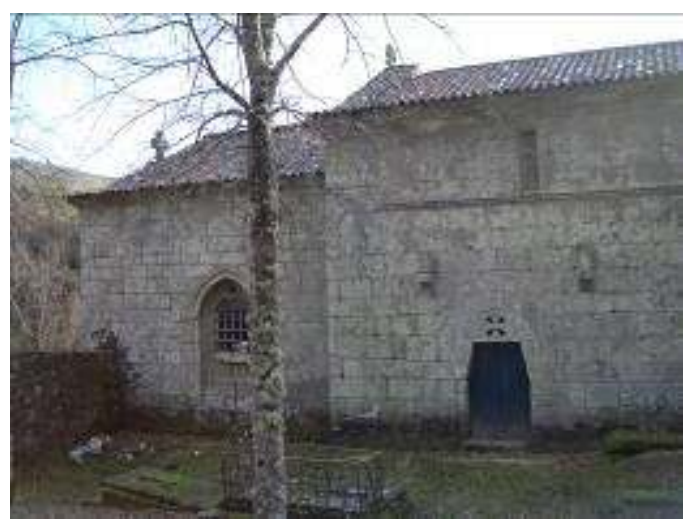

Fachada Norte da cabeceira onde de pode ver a janela do monge

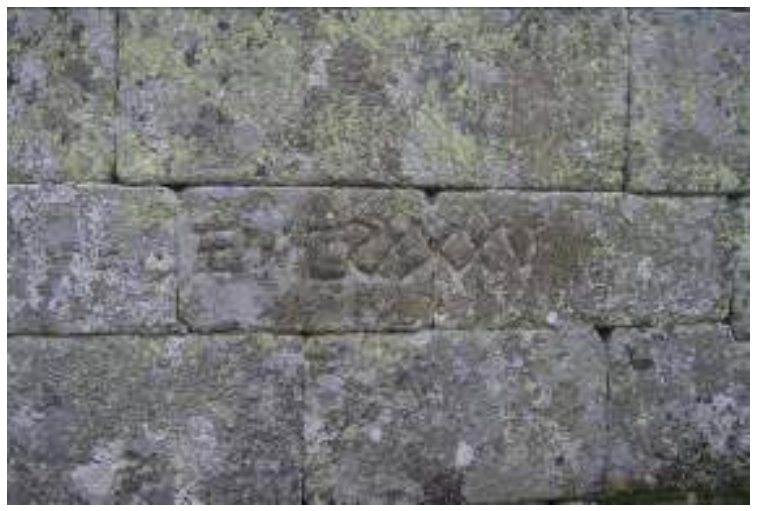

Data inscrita na fachada Norte da igreja

29 Na fiada das impostas, à direita da porta, entre a segunda e a terceira mísula, aparece uma inscrição, gravada em duas silhas, onde se pode ler, de acordo com a transcrição de Mário Barroca: Era $M^{a} C^{a} 2 X X X V^{a}$, que segundo o autor, deve ser lida como Era Hispânica de 1185, Anno Domini de $1147^{\mathrm{xix}}$. Considero haver aqui um erro de gráfica uma vez que Mário Barroca cita como correcta, em nota de rodapé, a leitura feita por Maur Cocheril no Routier des Abbayes Cisterciennes du Portugal, onde a data é transcrita como ERA : M.CLXXXV [ère chrétienne 1147] ${ }^{\mathrm{xx}}$

A fachada Norte da cabeceira é interrompida por uma janela, próxima da que encontramos na fachada nascente. Trata-se de uma janela de arco quebrado, geminada, cujo mainel foi destruído para dar lugar a uma janela quadrada, dividida em vidraças, com os cantos superiores boleados de forma a se adaptar à antiga moldura, de colunelos lisos, assentes em bases também elas lisas. Mantém-se ainda do original o tímpano trilobado que é vazado. Na base desta janela encontra-se uma das peças mais enigmáticas do conjunto, a escultura de um monge jacente, que apesar da degradação provocada pela erosão do tempo não deixa de impressionar, pelo menos pela estranheza da localização. A janela é bastante recuada como se quisesse proteger o monge das intempéries. Ao nível do plano da fachada existe uma segunda moldura de toreados contracurvados que formam um arco quebrado assente em colunelos lisos.

3.3 Fachada Lateral Sul

32 A fachada lateral Sul é delimitada à esquerda, ou seja a poente, pelo muro da cerca onde está a porta de entrada do mosteiro e a nascente por dois lances de escadas ${ }^{\mathrm{xx}}$ que davam acesso à sacristia. 
33 A fachada Sul é em tudo muito semelhante à fachada Norte, mantendo o mesmo esquema construtivo. É rematada superiormente por cornija moldurada, tem duas frestas perspectivadas, cinco mísulas, friso ornado, sendo a porta lateral alinhada com a da fachada oposta. Existem, no entanto, diferenças entre elas. Contrariamente ao que acontece na fachada Norte a decoração do friso é constante ao longo de toda a fachada. o friso é decorado com enxaquetado de quadrados esquinados sobrepostos em duas filas, em relevo fundo e com orla superior lisa. De salientar que, apesar do friso apresentar o mesmo padrão, foi esculpido de forma inversa comparativamente com o friso da fachada Norte; ou seja o que é cheio de um lado é escavado do outro.

As frestas, assentes sobre o friso, mantêm com este a mesma relação, comparativamente à fachada Norte. Pelo contrário as mísulas vão-se distanciar do friso, não duas mas três fiadas. Relativamente à sua decoração, enumerando-as de poente para nascente, encontramos a primeira e a última danificadas e sem decoração, a segunda decorada com enxaquetado de quadrados, a terceira com uma pequena roldana e a quarta, a mais próxima da porta, com um enlaçado formando uma espécie de caduceu. Sobre esta última, é ainda possível ver, duas fiadas acima, a marca deixada na fachada por um apoio de trave, possivelmente de madeira.

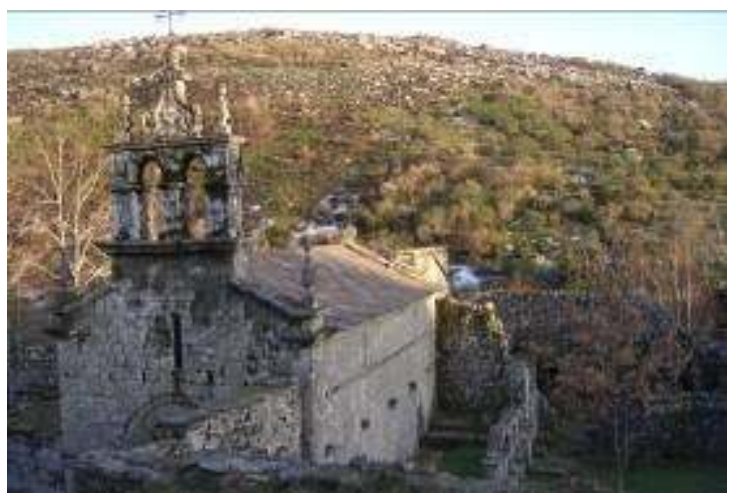

Fachada Sul

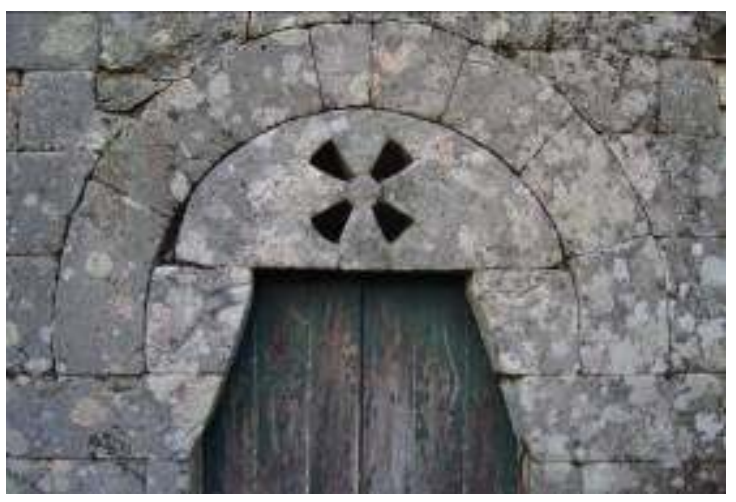

Porta Sul onde é visível o que sobrou do desenho do lintel.

Tal como acontece na fachada Norte, o portal tem o lintel cortado, só que, neste caso, não se trata de um lintel liso mas sim decorado. É visível, nas pedras que restaram do lintel, parte do desenho esculpido. Relativamente à sua decoração, Mário Barroca fala em "serpentes enlaçadas mordendo-se mutuamente"xxii, citando como exemplos os casos de São Pedro de Rates e São Pedro das Águias. Pela leitura que faço, das imagens que ficaram no que sobrou do lintel, aceito como mais provável a relação com o desenho gravado junto às pedras de fundação de S. Pedro das Águias, ou mesmo com os caduceus 
presentes noutras partes do edifício, do que com São Pedro de Rates, onde o que encontramos é uma espécie de uruborus.

Na fachada Sul da cabeceira, a descoberto devido à ruína da ala dos monges, é visível uma porta no piso térreo, actualmente entaipada, que fazia o acesso directo da cabeceira para a sacristia; e uma pequena janela rectangular ao nível do piso superior, também entaipada.

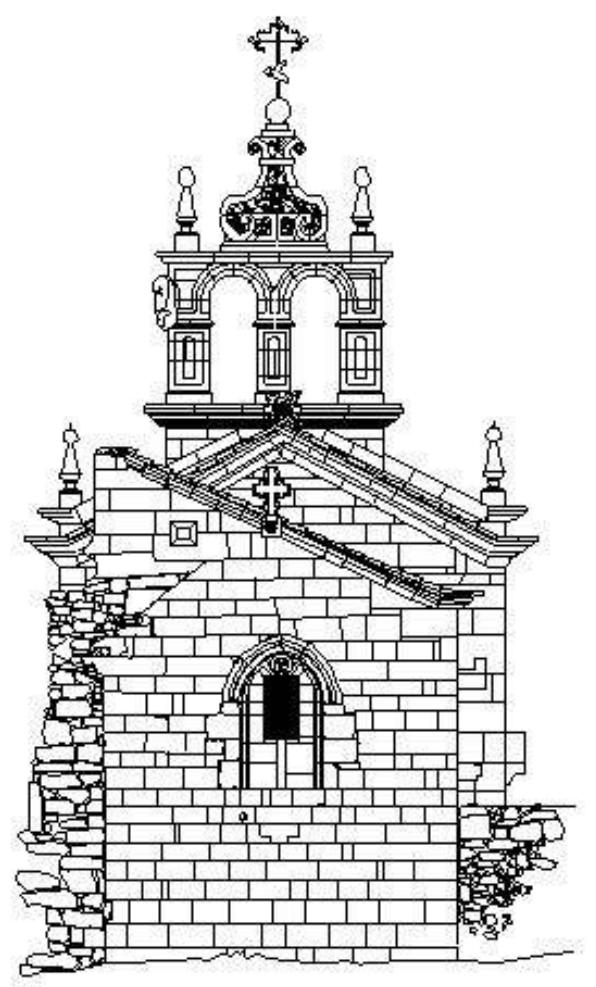

Levantamento arquitectónico do Alçado Nascente, segundo José Custódio

Por se erguer mesmo junto à ribeira esta fachada é de difícil acesso, sendo necessário atravessar a ponte, actualmente de madeira ${ }^{\text {xxiii }}$, para subir a encosta da serra donde se tem uma visão mais abrangente da fachada, que é praticamente tapada pela cabeceira.

Daí, para além da visão do conjunto, tem-se uma visão muito completa da empena Este da cabeceira delimitada à direita pelo muro do cemitério e à esquerda pela sacristia $\mathrm{e}$ pela ala dos monges. Uma vez que a cabeceira é mais baixa e mais estreita que a nave da igreja vê-se, em cima e à direita, parte da fachada posterior da nave. Esta é coroada por uma cruz rendilhada que apesar de danificada, mostra a construção geométrica da cruz orbicular. 


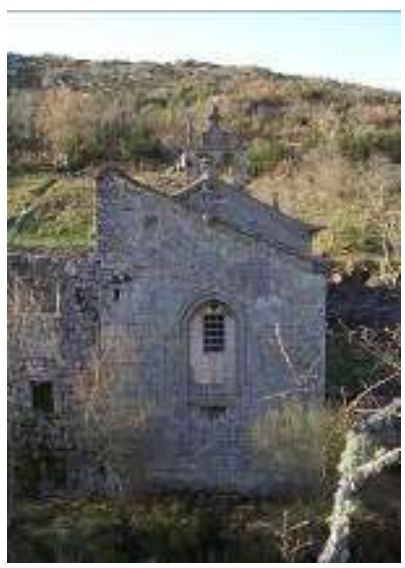

Fachada Este da cabeceira

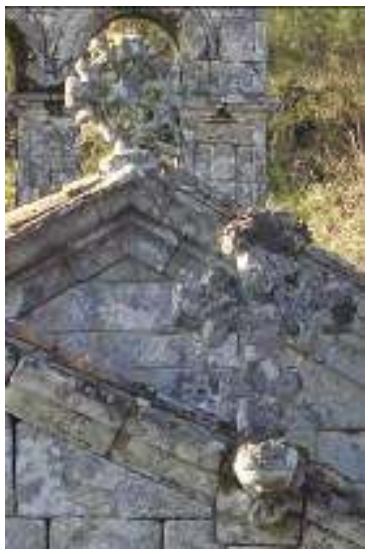

Coroamento das fachadas posteriores da nave e da cabeceira

40 A fachada nascente da cabeceira dá-nos informações preciosas sobre a evolução do edifício. Permite-nos ver, através da marca do beiral, que inicialmente a cabeceira era coberta por um telhado de duas águas. Por sorte foi deixada também a cornija original, que nos mostra que a cabeceira anterior era mais baixa. A cabeceira é alteada para se construir o segundo piso da ala dos monges, passando a cobertura do telhado a ser de uma só água, com pendor Sul - Norte para evitar problemas de infiltrações na ala dos monges. Do antigo telhado foi deixada a cruz latina trifoliada, que coroava a empena.

41 Ao centro da fachada abre-se uma janela, semelhante à janela da fachada Norte, embora mais estreita e menos perspectivada, foi igualmente alterada pelas diversas épocas. $\mathrm{Na}$ parte da empena que foi acrescentada, para fazer a alteração do telhado, abre-se uma pequena fresta quadrangular perspectivada. Tal como a nave da igreja, a empena da cabeceira é rematada superiormente por cornija emoldurada. Pela altura desta empena e pela diferença de cota, bem visível no desnível que se verifica ao longo de toda a fachada Norte, percebe-se que para construir a cabeceira o terreno teve que ser parcialmente aterrado.

3.50 interior da nave

43 A igreja é de nave única, com cobertura de madeira, pavimento em lajes de granito e cabeceira rectangular abobadada. No seu interior, a parede da fachada principal, é percorrida por dois frisos que se destacam do emparelhamento; um ao nível das impostas e outro ao nível da fresta. $O$ 
primeiro, ao nível das impostas, estende-se para um lado e para o outro do portal, ao longo de toda a fachada. Trata-se de um friso com motivos lanceolados e orla superior lisa, muito próximo daqueles que estão presentes nas arquivoltas do portal, tanto no exterior como no interior da nave. As diferenças verificam-se apenas ao nível da orla e no trabalho de gravação no interior das pontas de lança. o friso da arquivolta tem orla inferior lisa e o friso ao nível das impostas orla superior lisa. Além disso, no primeiro caso existe uma linha vertical que acentua a simetria da ponta de lança, que no segundo não se verifica. 0 segundo friso, mais elevado, está presente em todas as paredes da nave apresentando uma orla superior lisa que é constante em todos os alçados; no entanto, como veremos mais adiante, ele irá variar quer na altura quer na ornamentação.

O friso superior, parcialmente cortado pela fresta é ornado com três fiadas de bilhetes em relevo fundo e orla superior lisa, sendo a sua decoração constante ao longo de toda a fachada. A fresta, aberta tardiamente aquando do alteamento da fachada, apresenta, no interior da nave, um remate em arco de volta perfeita.

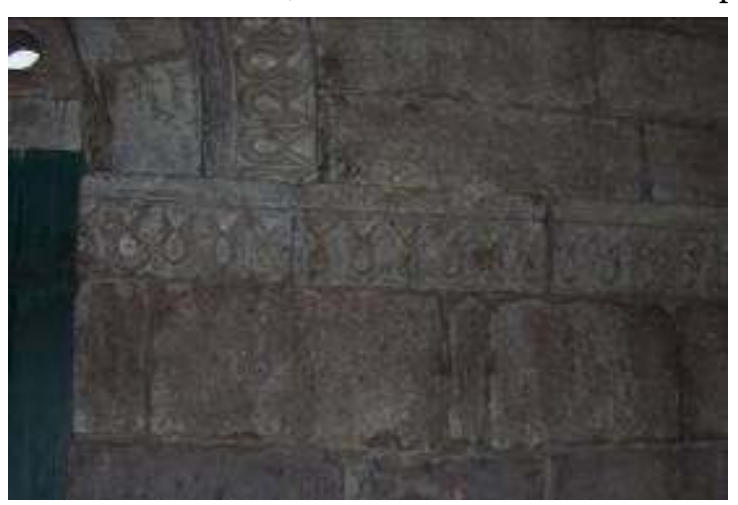

Pormenor dos frisos decorados com pontas de lança no interior da igreja.

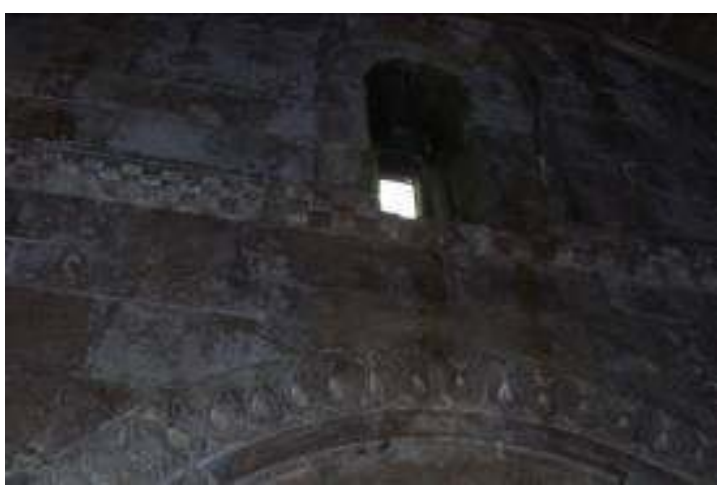

Pormenor do friso e a relação que estabelece com a fresta no interior da fachada principal.

Relativamente ao portal, continuamos a ter duas arquivoltas estruturais, a interior lisa e a exterior ornada apenas com o lanceolado anteriormente referido. Tanto o lintel como as mísulas não apresentam ornamentação interna. 


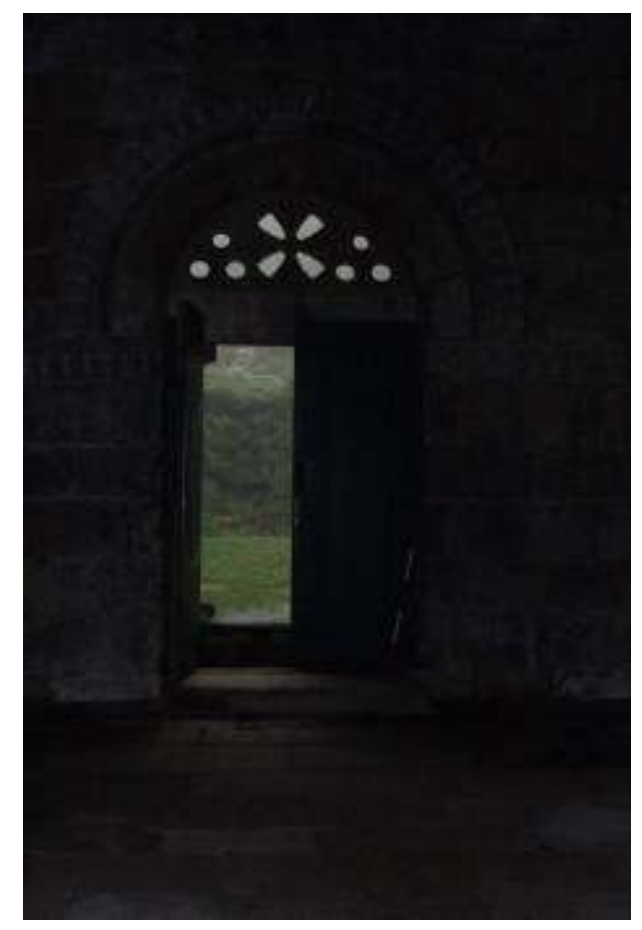

Portal principal visto do interior da nave.

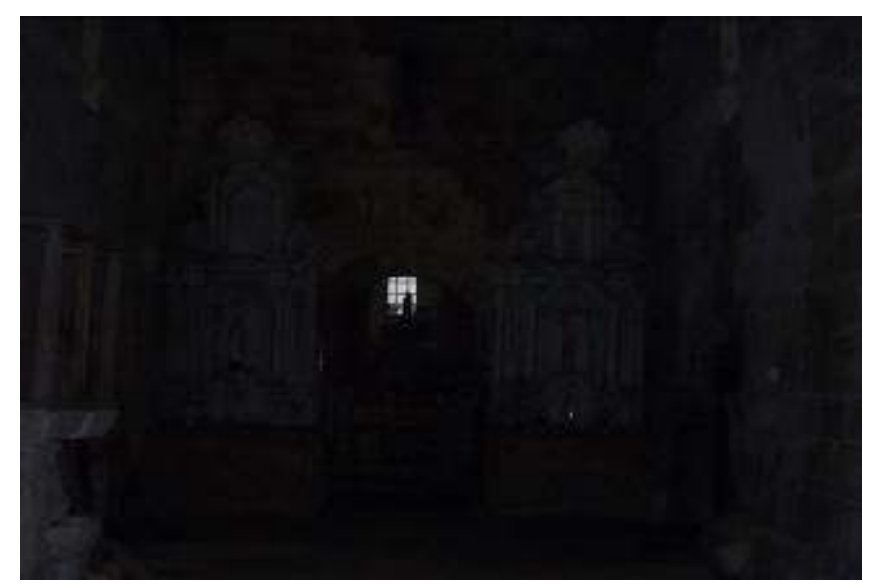

Alçado posterior da nave que faz a passagem para a cabeceira.

47 Na parede interior da fachada lateral Norte, o friso desce duas fiadas de pedra e altera a sua ornamentação. Continuamos a ter um friso mais saliente que o emparelhamento da fachada, embora em algumas zonas não pareça devido ao desgaste da pedra. A relação do friso com as frestas já não é a mesma. Enquanto na fachada principal o friso era apenas parcialmente cortado, aqui ele é totalmente interrompido. A ornamentação também não é constante ao longo de todo o friso; mantém-se a orla superior lisa, mas vamos encontrar três motivos diferentes que mudam sempre que o friso é interrompido pelas frestas. Assim temos, da esquerda para a direita, ou seja, da fachada principal para a cabeceira uma primeira ornamentação correspondente a duas linhas paralelas em zig-gag, estando o friso muito danificado nesta zona. Entre as duas frestas, voltamos a ter as três fiadas de bilhetes e a partir da segunda fresta o friso é ornado com um enxaquetado de quadrados esquinados sobrepostos em duas filas. Este último troço do friso não vai até ao limite da fachada, acontecendo exactamente o mesmo na fachada oposta. 

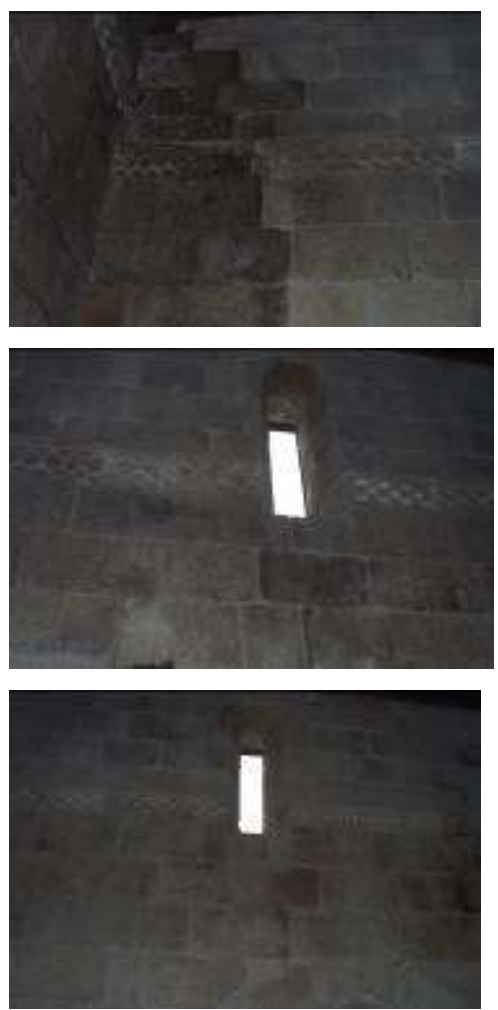

Variação do friso ao longo da fachada Norte.

48 Ao passar para o alçado posterior o friso mantém o mesmo alinhamento, no entanto, a relação com a fresta que se abre neste alçado já não é a mesma. $O$ friso passa no limite do arranque da fresta, ou seja, temos um friso contínuo, sem interrupções de uma ponta à outra da fachada. Quanto à ornamentação ela irá repetir a solução adoptada no alçado principal, ou seja, as três fiadas de bilhetes.

49 A parede interior da fachada lateral Sul repete a solução adoptada na fachada Norte. 0 friso é interrompido pelas frestas e a gramática ornamental varia em função das interrupções. Da esquerda (alçado posterior) para a direita (alçado principal) temos até à primeira fresta um enxaquetado com duas fiadas de quadrados esquinados; entre as frestas três fiadas de bilhetes e entre a segunda fresta e o alçado principal repete o enxaquetado com duas fiadas de quadrados esquinados ao início e no fim duas linhas em ziz-zag. Ou seja, este último troço do friso apresenta duas decorações diferentes; começa de facto com duas fiadas de quadrados esquinados, mas ao aproximar-se do final da fachada muda para as duas linhas em zig-zag.

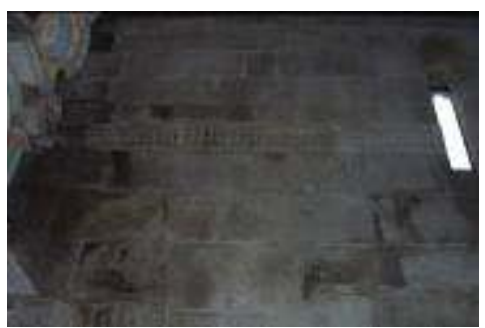



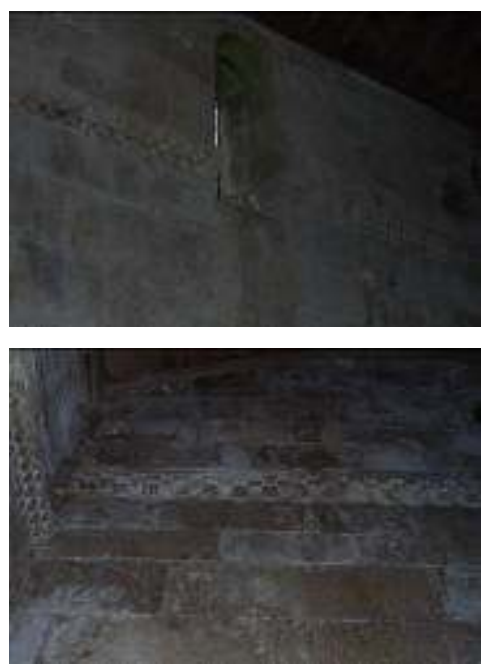

Variação do friso ao longo da fachada Sul e passagem para a fachada principal.

50 Se este último troço fosse todo em zig-zag, conseguia-se criar uma lógica de leitura na ornamentação dos frisos. Partindo do portal em direcção à cabeceira teríamos até às primeiras frestas, tanto de um lado como do outro, o motivo em zig-zag; entre as frestas (e nos alçados principal e posterior) as fiadas de bilhetes e por fim entre as segundas frestas e a parede do arco triunfal teríamos as fiadas duplas de quadrados esquinados.

51 Para além do que já se referiu relativamente ao alçado principal e ao friso que percorre todo o interior, a nave da igreja é desprovida de ornamentação. As paredes das fachadas laterais Norte e Sul, tal como acontece no exterior são muito semelhantes. Nelas encontramos as frestas perspectivadas com remate interno em volta perfeita e, próximas do alçado posterior, as portas travessas confrontantes.

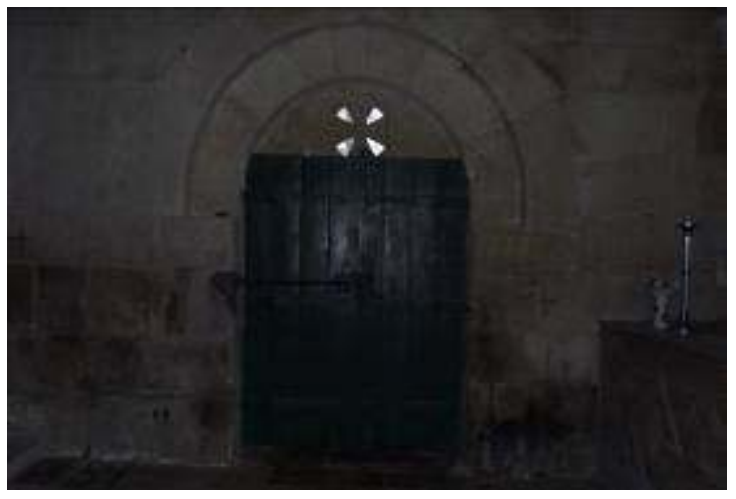

Porta Norte 


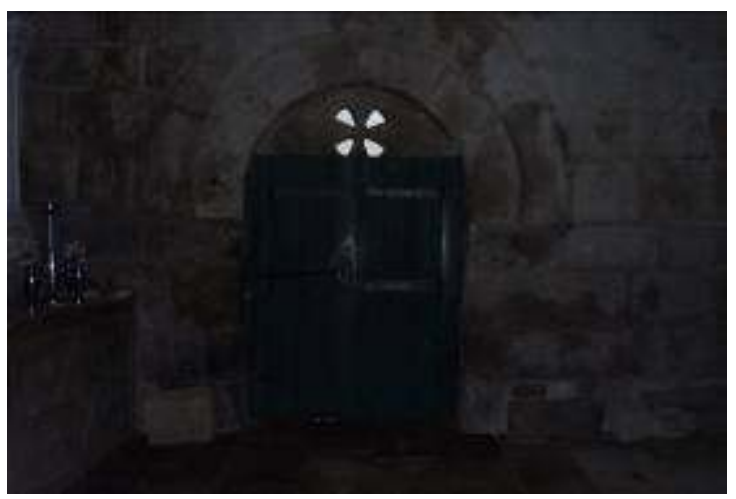

Porta Sul

52 São portas de arco de volta inteira levemente ultrapassado, com o tímpano vazado. As únicas diferenças que se encontram são ao nível da ornamentação das impostas. Assim relativamente à porta Norte, temos a imposta do lado esquerdo decorada com o motivo dos corações invertidos presos por presilha e orla superior lisa; a imposta do lado direito apresenta a mesma decoração do friso, duas fiadas de quadrados esquinados com orla superior lisa. A avaliar pelo aspecto da pedra e pelos vestígios de cimento, parece claro, tanto num caso como noutro, que se trata de pedras recentes.

53 Na porta virada a Sul, encontramos na imposta do lado esquerdo, o mesmo motivo dos corações invertidos: no entanto, trata-se de uma representação muito diferente da anteriormente citada e mesmo diferente da representada no friso ao nível das impostas no portal principal (exterior). Enquanto que nos casos anteriores o motivo descrito pelos arcos era de volta plena aqui temos um arco quebrado bastante acentuado. A imposta do lado direito, repete a decoração do lintel do portal principal da igreja, tendo tal como o anterior uma orla superior lisa.

54 Entre as duas frestas, colado à fachada Norte, aparece um púlpito claramente posterior ao edifício. Trata-se de um púlpito muito simples, com varandim e corrimão de madeira, feito a partir de pedras reaproveitadas, agregadas com cimento. No pilar que sustenta a base do púlpito, é visível uma gravação e a servir de apoio ao terceiro degrau está uma pia.

O alçado posterior da nave, faz a passagem para a cabeceira através de um arco triunfal com duas arquivoltas lisas que descarregam em ábacos chanfrados, decorados com esferas soltas em alto-relevo.

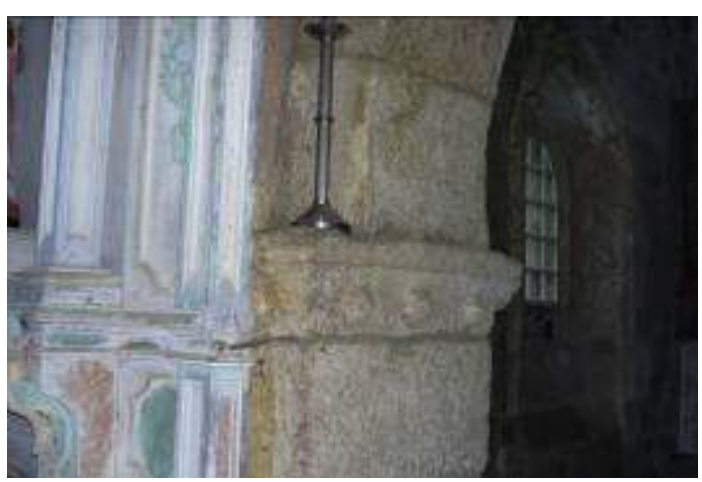




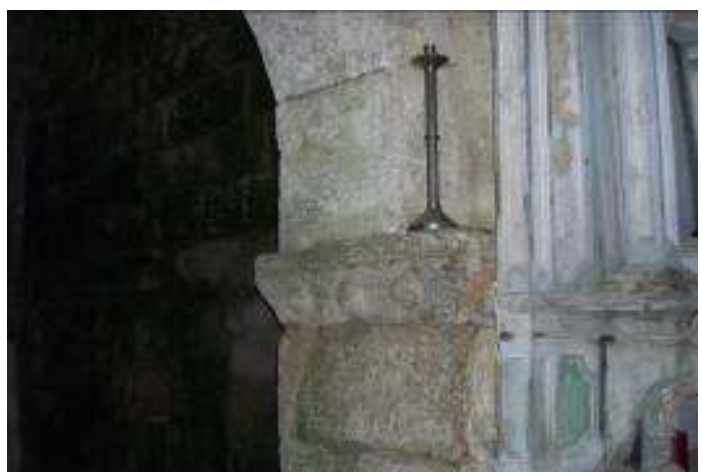

Ábacos do arco triunfal.

\section{triunfal. Esta fresta é emoldurada por dois bocéis donde saem pequenas volutas,} gravadas sobre a pedra, formando uma composição simétrica.
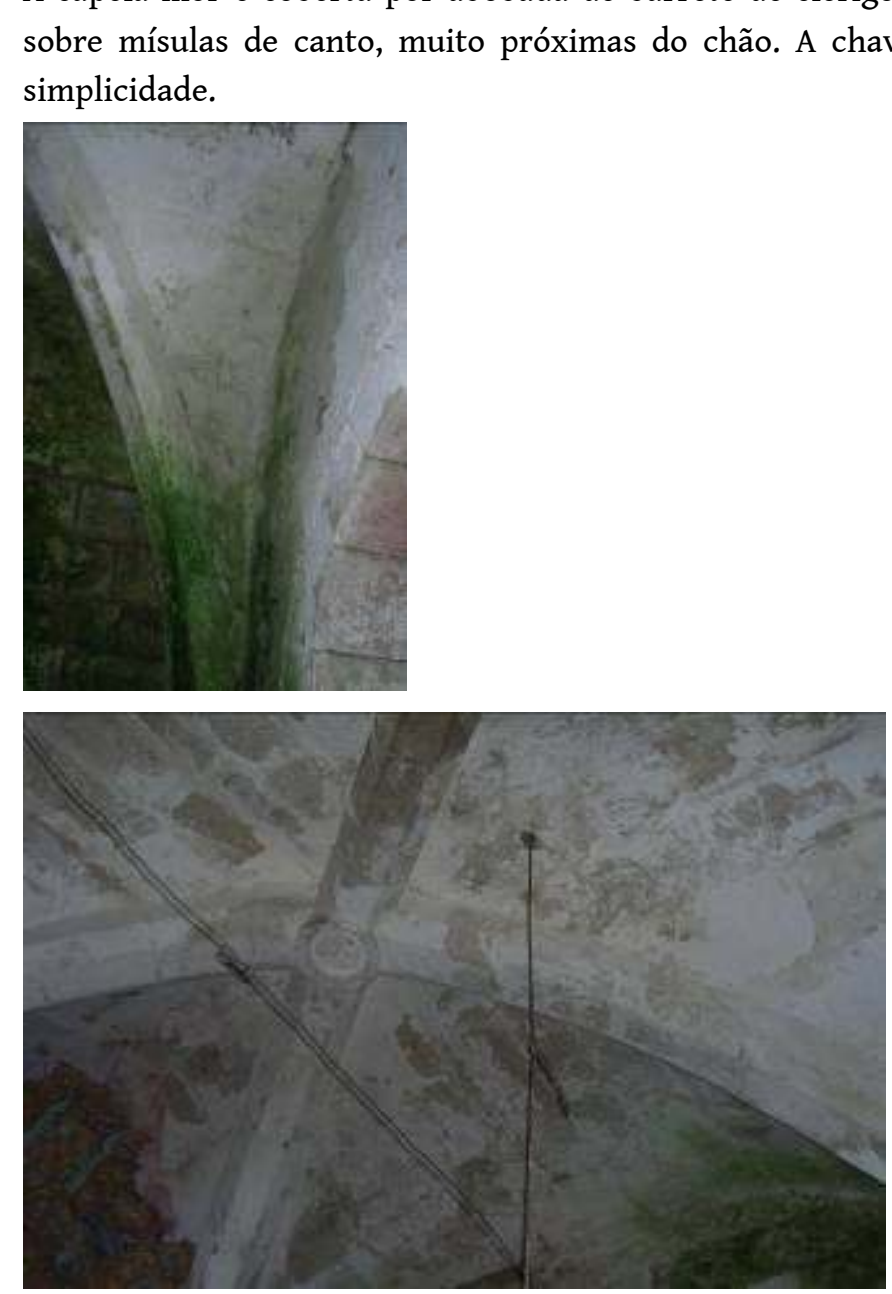

Pormenores do tecto abobadado da cabeceira

A fachada Sul, pela ruína das dependências monásticas ou por uma solução arquitectónica mal resolvida, mostra com evidência a humidade que o verdete das paredes não consegue esconder. É ainda visível a porta que fazia a passagem para a 
sacristia, actualmente entaipada. Nessa mesma passagem, junto ao chão aparece uma pequena abertura semicircular coroada por uma cruz latina e ladeada por dois pináculos, em alto-relevo. À esquerda da porta, não muito acima do nível do chão, surge um pequeno nicho. A fachada Este, totalmente coberta pelo altar-mor, é iluminada através de uma janela, virada a nascente, seguindo as mesmas regras de orientação do templo romano. ${ }^{\text {xxiv }} \mathrm{Na}$ fachada Norte fica a janela do monge, muito semelhante à anterior, mas colocada três fiadas a baixo. Trata-se de uma antiga janela geminada, de arco quebrado e tímpano trilobado vazado, substituída posteriormente por uma janela de vidraças. Da janela original mantém-se ainda o tímpano e os toreados da moldura. São visíveis restos de pintura na pedra que forma a moldura. À esquerda da janela há um pequeno nicho, com arco ultrapassado talhado numa única pedra. À esquerda do nicho, apanhando duas silhas, surge um rasgo rectangular que terá servido de encaixe a uma qualquer estrutura.

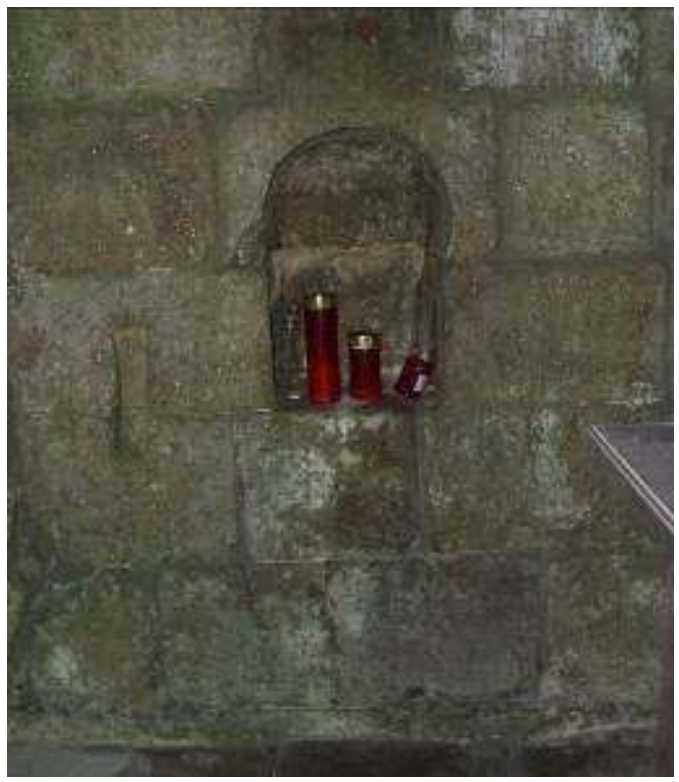

Nicho

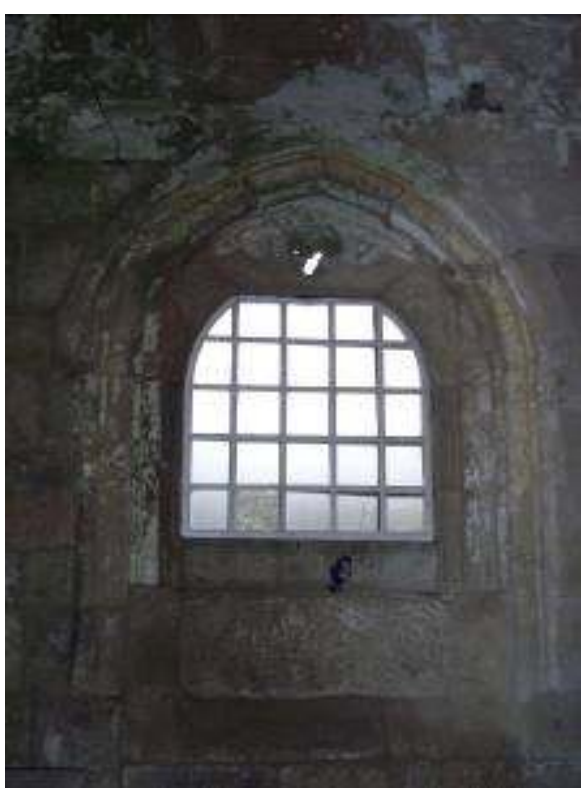

Janela do monge 
É por cima deste nicho que aparece, gravado na pedra, uma marca de canteiro, em linha dupla, representando o símbolo do infinito. Podemos encontrar a mesma marca reproduzida várias vezes no dormitório de Alcobaça, no interior da igreja de Tarouca e também numa parede das fundações das dependências monásticas do mesmo mosteiro. Esta mesma sigla aparece esculpida em alto-relevo, como elemento ornamental, num capitel do Mosteiro de Santa Maria de Oseira ${ }^{x x}$.

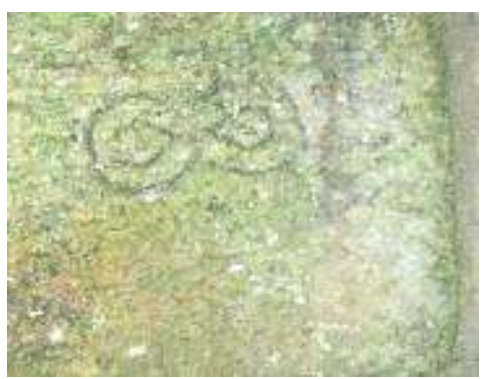

Marca de canteiro gravada na parede norte da cabeceira.
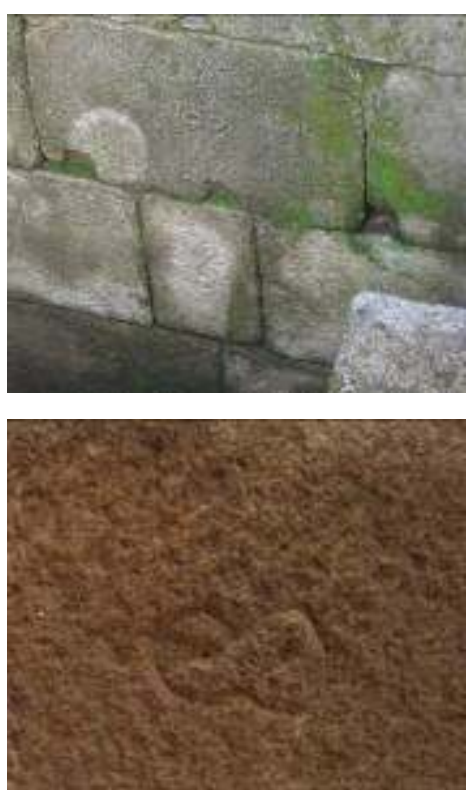

Marcas de canteiro nas dependências monásticas (em cima) e na parede Sul da igreja do Mosteiro de Tarouca (em baixo)

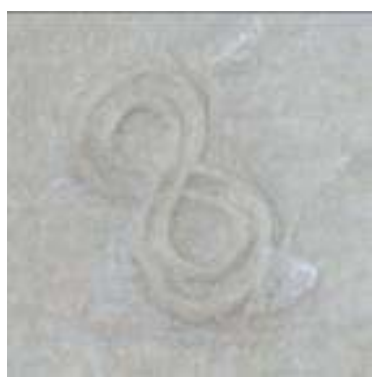




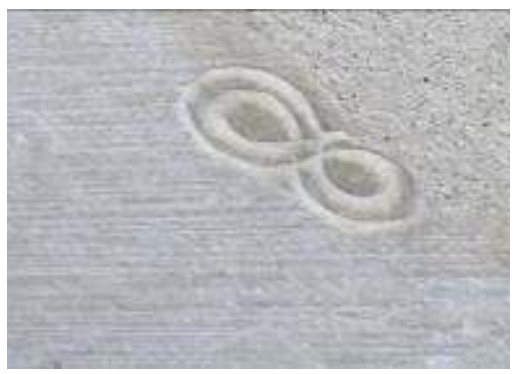

Marcas de canteiro gravadas numa das paredes do dormitório do Mosteiro de Alcobaça. principal da igreja. Esse pedaço de cerca, perpendicular à fachada principal da igreja, na continuação da fachada Sul, estende-se até à encosta Oeste. A entrada no mosteiro faz-se por uma porta rectangular, num muro de emparelhamento pouco cuidado, que evidência uma construção mais tardia. Mais evidente do interior do que do exterior, é visível a solução arquitectónica adoptada para o alívio das cargas. No interior, à esquerda da porta, vê-se ainda uma pequena janela quadrada.

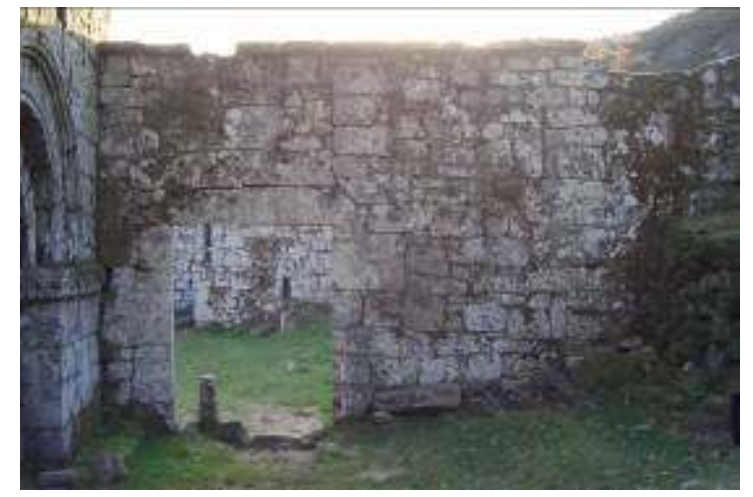

Vista exterior da entrada do mosteiro

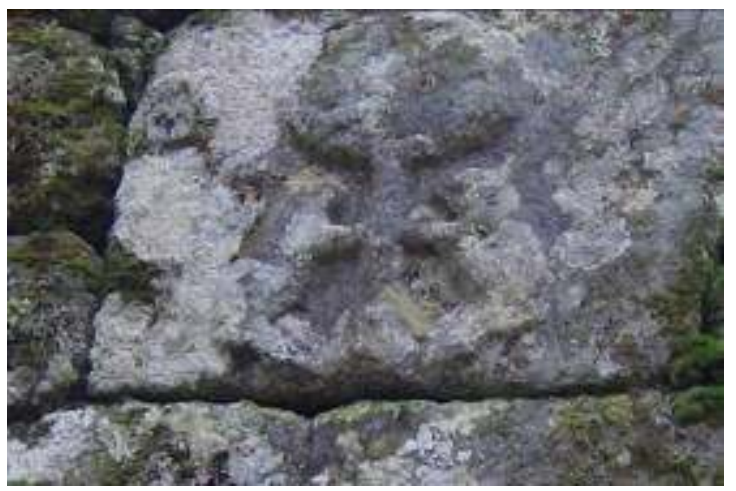

Símbolo de Oseira, esculpido em alto-relevo, por cima da porta de entrada.

Por cima da porta da entrada há uma pedra rectangular com o símbolo de Oseira, esculpida em alto-relevo, onde se vê os dois ursos ladeando uma árvore; a mesma imagem que se vê pintada no retábulo de madeira, à esquerda do arco triunfal, no interior da igreja.

64 Quando se entra no espaço do mosteiro confrontamo-nos de imediato com as dependências anexas à cozinha, que a sua grande chaminé não deixa passarem 
desapercebidas. À nossa esquerda encontramos o que resta das arcadas do claustro e, adossada à sacristia, a ala dos monges.
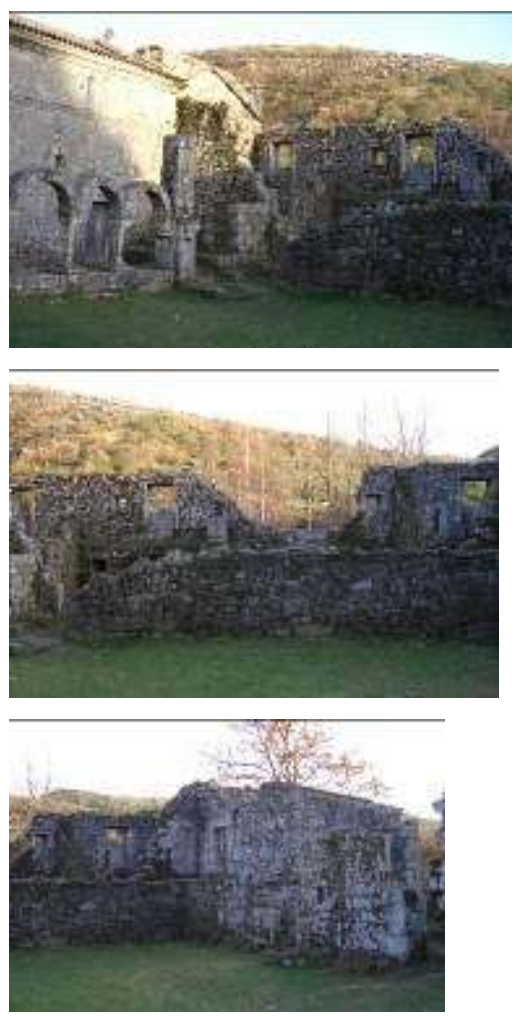

Ala dos monges

A ala dos monges é composta por um corpo construtivo em L, com dois pisos construídos ao longo da ribeira. Embora esteja muito degradada é ainda possível fazer a reconstituição das suas dependências: cinco no piso superior e seis no piso térreo ${ }^{\text {xxvi }}$. Era coberta por um telhado de duas águas, ainda visível através do remate por encosto (vulgarmente denominado por guarda-fogo) na fachada Sul da cabeceira. Adossado à última dependência, já virado para Sul, há outro bloco de dois pisos, com escadas de acesso ao piso superior e empena de duas águas assimétricas. Na fachada virada a nascente, no piso superior, são visíveis cinco janelas com pedra conversadeira e duas quadradas de menores dimensões. No piso térreo, da mesma fachada, restam cinco janelas quadradas e duas frestas muito perspectivadas. Nas duas dependências viradas a Sul há uma fresta muito perspectivada e duas janelas, sendo que uma delas está entaipada.

A Cozinha situada a Sudoeste marca a sua presença pela grande chaminé de forma piramidal com pináculo de remate boleado. Foi ampliada no século XVIII, quando se construíram as dependências anexas, utilizando o mesmo esquema construtivo da arquitectura vernácula da regiãoxxvii. Está colocada no piso superior e tem um forno circular anexo. É uma chaminé de canto, em granito, apoiada sobre coluna. Nas dependências anexas à cozinha encontra-se um antigo sarcófago, encaixado entre duas divisões, que foi reaproveitado para recolha das águas trazidas do exterior. Essa recolha é feita através de uma conduta de pedra que sobe a encosta até uma fonte, conduzindo a água daí até ao interior do mosteiro. 


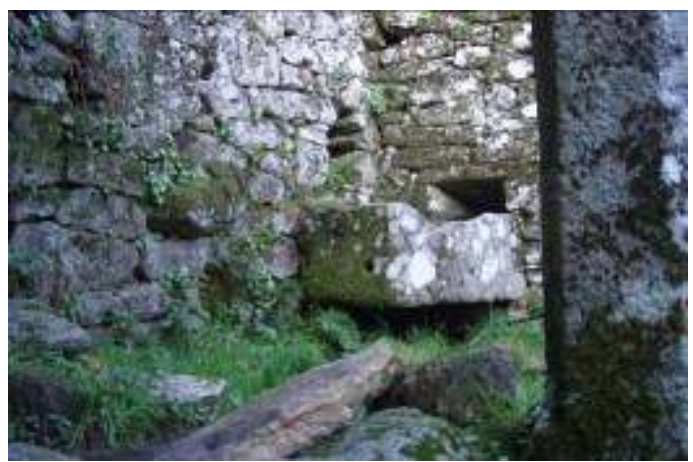

Antigo sarcófago que faz a recolha das águas no interior das dependências anexas à cozinha

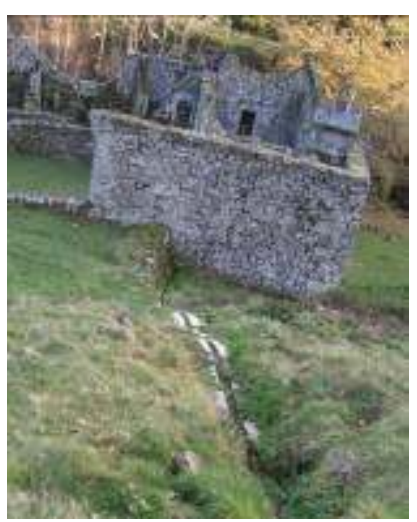

O percurso da calha de pedra até entrar no Mosteiro.

67 A fachada Sul deste bloco é constituída por uma empena de duas águas praticamente cega, sendo visíveis apenas duas pequenas aberturas. Dá continuidade à empena, sobrepondo-se mesmo à aba esquerda do telhado, o muro da cerca que ao virar para poente, devido à subida da cota, é interrompido e rematado pelo que resta de um arco em bisel. A partir daí o topo do muro fica à mesma cota do terreno restando apenas o muro que sustenta a encosta.

Quando o muro vira para norte, ficando perpendicular à fachada principal da igreja, a cota volta a descer e o muro retoma a sua função de cerca. Do lado oposto, a Sul, a ligação entre o edifício da cozinha e a ala dos monges era feita por um muro, entretanto desaparecido, não contíguo à fachada exterior dos edifícios.

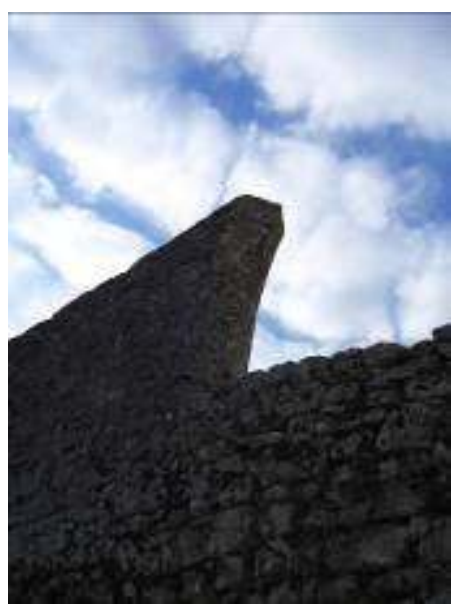

Arranque do arco em bisel visto de dentro das dependências monásticas 


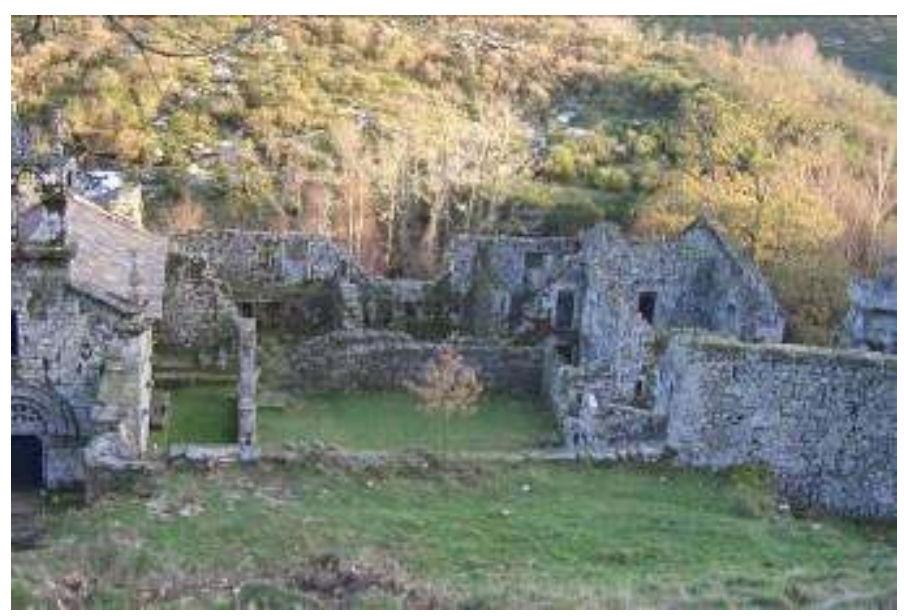

Vista geral do mosteiro onde se vê a interrupção da cerca com o muro a fazer apenas a sustentação do terreno da encosta

Do complexo monástico original nada subsiste. Como se pode verificar pelas edificações que ainda restam, e pelo emparelhamento pouco cuidado das mesmas, estamos na presença de construções tardias. Para reconstituir o projecto original seria necessário dar continuidade ao projecto arqueológico iniciado em 1993. Quanto ao claustro, admite-se ter sido construído numa altura em que o mosteiro ainda não seguia a regra de Cister, ou pouco depois da adopção da mesma. Para além de alguns vestígios no terreno restam apenas três arcadas paralelas à fachada Sul da igreja e o canto das arcadas viradas a nascente. $O$ conjunto das arcadas do claustro é composto por três arcos de volta perfeita, que descarregam ao centro sobre pequenas colunas geminadas e nos extremos sobre pilares quadrangulares. É muito regular ao nível das proporções. $O$ arranque dos arcos é um prisma pentagonal, assente sobre ábaco quadrangular chanfrado. Este, por sua vez, assenta sobre o capitel de base igualmente quadrada em forma de cálice de flor que estreita formando um rectângulo que encaixa no fuste. Os capitéis são decorados com folhas e volutas. O fuste, formado por dois cilindros secantes com uma nervura longitudinal nas zonas de intersecção, é liso tendo uma aparência mais delicada quando é visto no sentido Norte-Sul, uma vez que aparenta ter apenas metade da espessura. A base é lisa e assenta sobre o muro do claustro cuja altura é variável. Os pilares quadrangulares, totalmente lisos, apresentam o mesmo ábaco biselado, sob o qual se adossa, de cada lado do pilar, uma mísula em forma de meio capitel, que serve de apoio ao arco. Segundo Mário Barroca ${ }^{\mathrm{xxviii}}$, as alas do claustro eram pavimentadas com lajes de granito que se encontram soterradas, a uma cota média de $30 \mathrm{~cm}$, devido aos sucessivos assoreamentos. O seu levantamento arqueológico permitiria, segundo o mesmo autor, recuperar não só o pavimento original e as dimensões exactas da quadra, como ainda aferir a existência ou não de sepulturas no claustro. Informações posteriores da DGEMN confirmam a existência de dois tipos de sepulturas na ala norte do claustro; umas em caixa com pequenas lajes graníticas e outras, mais antigas, escavadas em depósitos de argila, uma das quais com recorte antropomórfico. 


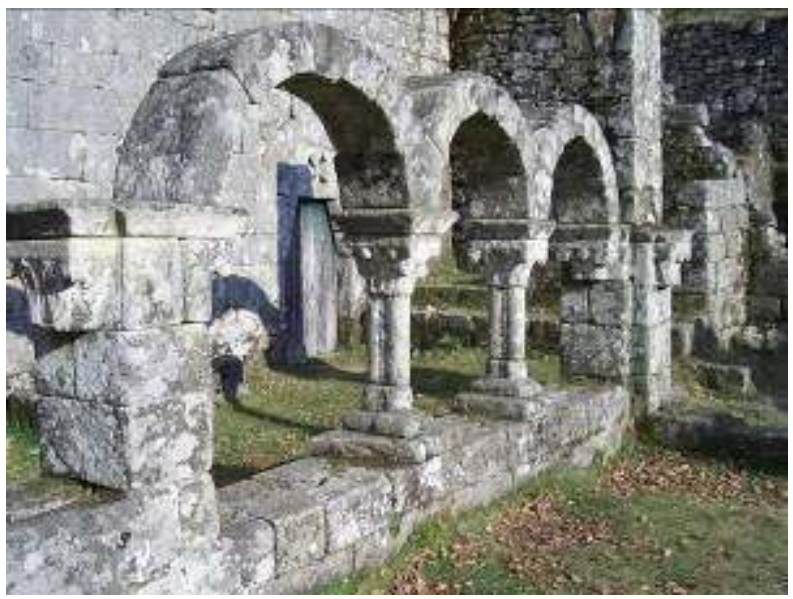

Arcadas do claustro

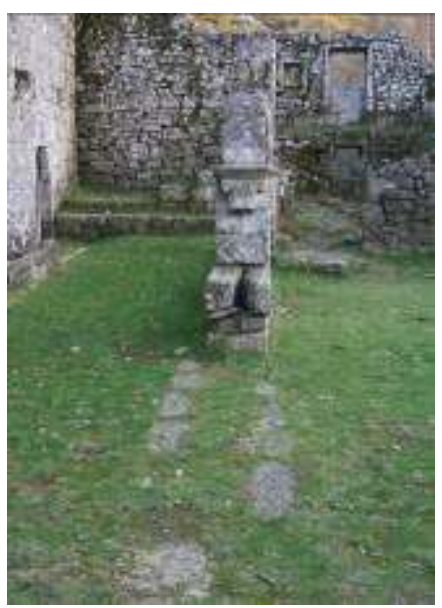

Vestígios no terreno do alinhamento das arcadas do claustro

\section{ALGUMAS CONSIDERAÇÕES MÉTRICAS SOBRE O EDIFÍCIO}

Através das sucessivas aproximações ao edifício foi-se tornando claro que aquelas paredes encerram um conhecimento mais vasto do que à primeira vista poderia parecer. A beleza intrínseca do edifício, a sua proporção e harmonia não lhe advêm do facto de se tratar de uma pequena construção, com recursos financeiros restritos, para um número igualmente restrito de monges. Estamos perante um edifício de pequena escala, construído num vale isolado, numa zona irrigada, bem ao gosto cisterciense e que foi construído por alguém que conhecia bem as regras da geometria e da métrica dos edifícios, nomeadamente a aplicação de regras vitruvianas.

A igreja, segundo medições da DGEMN, tem 7,10 metros de largura. Se fizermos a conversão para pé de rei $(0,3248 \mathrm{~m})$, medida habitualmente usada em edifícios religiosos, não obtemos um valor certo $(21,85)$; no entanto, se fizermos a conversão para outra medida mais antiga, o pé romano $(0,295 \mathrm{~m})$, obtemos um valor mais exacto $(24,06)$, ou seja, a largura da igreja corresponde a 24 pés romanos, o que denota a existência de uma estrutura anterior, sugerida ainda pelo tamanho da nave, que é duas vezes o comprimento da largura da fachada, como recomendava Vitrúvio, no capítulo IV do seu quarto livro: "O comprimento do templo é planeado de modo que a largura corresponda a metade daquele...". Existe de resto uma correspondência entre o templo pagão romano e 
o templo cristão, que aqui também se verifica, relativamente à orientação dos edifícios e dos seus altares/ara; ambos se orientavam a nascente.

O mesmo já não acontece com o claustro, de construção mais tardia, numa altura em que o Mosteiro já tinha provavelmente abraçado a ordem cisterciense. Segundo os cálculos de Mário Barroca, feitos a partir da medida da arcada que resta hoje em dia do claustro, a quadra interior do mesmo mediria $10,40 \mathrm{~m}^{\text {xxix }}$. A conversão dessa medida para pé romano dá um valor inexacto $(35,25)$, no entanto a sua conversão para pé de rei revelou grande exactidão: 32 pés de rei $(32,01)$.

Se por um lado a métrica encontrada para a igreja, nos pode revelar a existência de um edifício anterior à sua construção, nas fundações do qual esta terá sido levantada, o claustro, seguindo uma métrica diferente, fala-nos de um rigor que não é alheio à forma de estar dos cistercienses. O número trinta e dois, segundo Rábano Mauro, refere-se "misticamente à idade que Nosso Senhor cumpriu na carne, daí que (como parece a alguns) diga o Apóstolo (Ef 4,13): "Até que todos tenhamos chegado à unidade da fé e do conhecimento do Filho de Deus, até atingirmos a idade de homem feito, na medida da idade da maturidade de Cristo". Se atendermos à importância do claustro na vida monástica e a tudo o que ele representava, poderemos ignorar esta coincidência?

Também o tímpano e o lintel, do portal principal, nos mostram algumas coincidências que vale a pena referenciar. Como já foi dito o lintel é ornado com uma banda de quadrifólios, ou seja, bandas de circunferências que se intersectam formando um padrão geométrico. Essa construção geométrica é a base construtiva da cruz vazada no tímpano, que por sua vez, resulta da intersecção de sete circunferências. No tímpano, como também já vimos estão representadas sete estrelas. E na pedra do lintel existe ainda um ponto gravado que é o centro geométrico das circunferências que desenham o tímpano e as arquivoltas do portal. Perante estas coincidências, que nos levam a acreditar mais no rigor do que no acaso e perante a inegável beleza que este edifício comporta, acredito que ele tem muito para dar e mais ainda para nos surpreender.

\section{CONCLUSÃO}

Assim, por tudo o que aqui foi exposto, creio termos reunido condições para lançarmos um olhar diferente sobre este edifício singular e, acima de tudo, procurarmos preservar um património que há décadas está à mercê das mais variadas intempéries.

Implantado num local isolado, abundantemente irrigado, reúne através da pastorícia as condições necessárias à sobrevivência do mosteiro e da sua comunidade monástica. É além disso um local de passagem de peregrinos e terá desempenhado, certamente, um papel importante na definição dos limites do território nacional. Esteve alternadamente ligado ao mosteiro galego de Santa Maria de Oseira, cuja presença se vê ainda na pedra lavrada que encima a entrada das dependências monásticas e nas armas pintadas nos altares policromos que ladeiam o arco triunfal no interior da nave, e a Santa Maria do Bouro.

79 A igreja de Pitões em termos tipológicos enquadra-se no românico da região de Braga e da bacia do Cavado, apresentando uma só nave com capela-mor de paredes rectas e planta rectangular. As suas reminiscências visigóticas manifestam-se não só pela persistência de um vocabulário ornamental, de carácter geométrico e vegetalista mas também pelos vestígios da presença do nartex.

Não creio que devamos procurar respostas neste mosteiro com base no pressuposto de estarmos perante uma pequena comunidade monástica, com escassos recursos 
económicos e ingenuidade artística. Não é disso que o edifício nos fala. A sua métrica parece indiciar a existência de um local de culto mais remoto, que remontará ao período romano, nas fundações do qual se terá erigido o edifício românico.

\section{BIBLIOGRAFIA}

ALMEIDA, Carlos Alberto Ferreira de - História da Arte em Portugal - O Românico - vol. III, Lisboa: Alfa, 1986.

ALMEIDA, Carlos Alberto Ferreira de - História da Arte em Portugal - O Românico - Editorial Presença: Lisboa, 2001.

ALMEIDA, Carlos Alberto Ferreira de - Arquitectura Românica de Entre Douro e Minho - Dissertação de Doutoramento em História da Arte apresentada à Faculdade de Letas da Universidade do Porto, Porto, 1978.

BARROCA, Mário Jorge - "Mosteiro de Santa Maria das Júnias - Notas para o estudo da sua evolução arquitectónica", in Revista da Faculdade de Letras da Universidade do Porto, II série, vol. 11, Porto, 1994, pp. 417-443.

BORRALHEIRO, Rogério - Montalegre - Memórias e História - Montalegre: Barrosana, E.M., 2005.

COSTA, João Gonçalves da - Montalegre e Terras de Barroso - Montalegre: Câmara Municipal de Montalegre, 1987, pp.120-132.

COUCHERIL, Maur - Routier des Abbayes Cisterciennes du Portugal - Paris: Fondation Calouste Gulbenkian, Centre Cultural Portugais, 1986.

GARCIA, José Manuel - Religiões Antigas de Portugal, Aditamentos e Observações às "Religiões da Lusitânia" de José Leite de Vasconcelos - Lisboa: Imprensa Nacional - Casa da Moeda, 1991, p. 550.

GULBENKIAN, Fundação Calouste, Guia de Portugal. Trás-os-Montes e Alto-Douro. I - Vila Real, Chaves e Barroso, vol. V, tomo 1, Coimbra, 1995, pp. 498-505.

GUSMÃO, Artur Nobre de - Românico Português no Noroeste - Lisboa: Veja, 1992.

LIMA, Alexandra Cerveira Pinto Sousa - "O Mosteiro de Santa Maria das Júnias: povoar e organizar um território de montanha”, in Cister. Espaços, Territórios, Paisagens, vol. II, Lisboa: Ministério da Cultura/IPPA, 2000.

MARQUES, José - A Arquidiocese de Braga no século XV - Lisboa: 1988.

MAURÍCIO, Rui Paulo Duque - "O Mosteiro de Santa Maria das Júnias: a construção e a paisagem”, in Cister. Espaços, Territórios, Paisagens - vol. II, Lisboa: Ministério da Cultura/IPPA, 2000.

NEIRA, M. Damian Yañez - "Datos para la historia del Monasterio de Junias", in separata da revista Bracara Augusta - vol. XXXII, Fasc. 73-75, Braga: 1978.

PÉREZ, José Carlos Valle - La Arquitectura Cisterciense en Galicia - vol. I e II, Coruña: Fundación Pedro Barrié de la Maza, 1986.

SOUSA, Bernardo - Ordens religiosas em Portugal. Das Origens a Trento - Guia Histórico - Lisboa: Livros Horizonte, 2006, pp. 106-107. 
VASCONCELOS, Joaquim - A Arte Românica em Portugal, Publicações Dom Quixote: Lisboa, 1992.

www.dgemn.pt

www.ippar.pt

\section{NOTAS DE FIM}

i. Estão desactualizadas as descrições de Maur Cocheril "Pitões est une petit localité, aux maisons basses faites de gros blocs de granit empilés, aux ouvertures rares, couvertes de chaume, étalée sur un sommet aplani par l'érosion"e do Guia de Portugal (Gulbenkian) "Pitões das Júnias, vetustíssima povoação agro-pastoril, de uma centena de choupanas, quase todas ainda cobertas de colmo (..) Na aldeia há apenas cinco casa cobertas de telha. As restantes, em conjunto de estranha beleza, são choupanas de colmo..." relativamente à cobertura das casas da aldeia. Actualmente as casa são praticamente todas cobertas de telha.

ii. Guia de Portugal. Trás-os-Montes e Alto-Douro. I - Vila Real, Chaves e Barroso, Vol. V, tomo 1, Coimbra: Fundação Calouste Gulbenkian, 1995, p. 500 e João Costa Montalegre e Terras de Barroso - Montalegre: Câmara Municipal de Montalegre, 1987, pp. 122.

iii. Mário Barroca - "Mosteiro de Santa Maria das Júnias - Notas para o estudo da sua evolução arquitectónica", in Revista da Faculdade de Letras da Universidade do Porto, II série, vol. 11, Porto, 1994, p. 419.

iv. José Manuel Garcia - Religiões Antigas de Portugal, Aditamentos e Observações às "Religiões da Lusitânia" de José Leite de Vasconcelos - Lisboa: Imprensa Nacional - Casa da Moeda, 1991, p. 550.

v. Bernardo Sousa, citando Fr. Tomás de Peralta, p. 106; Maur Cocheril, p.68; Mário Barroca, pp. 419-420, entre outros

vi. A data proposta por Maur Cocheril - Routier des Abbayes Cisterciennes du Portugal - p. 67 é anterior. «En 1247, un bref d'Innocent IV intimait à l'archevêque de Braga de ne pas se opposer à l'affiliation de Júnias à l'ordre de Cîteaux.» A DIrecção-Geral dos Edifícios e Monumentos Nacionais na informação que disponibiliza no sítio da Internet fala ainda, relativamente à bula papal, da união do mosteiro beneditino de Júnias ao cisterciense de Santa Maria do Bouro.

vii. Mário Barroca - Mosteiro de Santa Maria das Júnias - Notas para o estudo da sua evolução arquitectónica, in Revista da Faculdade de Letras da Universidade do Porto, II série, vol. 11, Porto, 1994, p. 423.

viii. João G. Costa, - Montalegre e Terras de Barroso - Montalegre: Câmara Municipal de Montalegre, 1987, p. 130, DGEMN e Mário Barroca Mosteiro de Santa Maria das Júnias - Notas para o estudo da sua evolução arquitectónica, in Revista da Faculdade de Letras da Universidade do Porto, II série, vol. 11, Porto, 1994, pp. 428-429.

ix. Direcção-Geral dos edifícios e Monumentos Nacionais

x. Direcção-Geral dos edifícios e Monumentos Nacionais

xi. Carlos Alberto Ferreira de Almeida- Arquitectura Românica de Entre o Douro e Minho - Vol. II, Dissertação de Doutoramento em História da Arte apresentada à Faculdade de Letras da universidade do Porto, 1978, p. 141 refere-se a uma capela-mor quadrangular: Pitões apresenta igreja de uma só nave com cobertura de madeira e capela-mor quadrangular. De acordo com as plantas da DGEMN a capela-mor é rectangular.

xii. Carlos Alberto Ferreira de Almeida - Arquitectura Românica de Entre o Douro e Minho - Vol. II, Dissertação de Doutoramento em História da Arte apresentada à Faculdade de Letras da universidade do Porto, 1978, p. 95 
xiii. É incompleta a descrição que Maur Cocheril faz, no Routier des Abbayes Cisterciennes du Portugal, relativamente ao tímpano do portal da fachada principal, ignorando os seis furos vazados que ladeiam a cruz: "La porte d'entrée, en plein cintre à deux archivoltes, est ornée d'un tympan d'une seule pierre percée de quatre ouvertures formant une croix de Malte. Les deux portes latérales, au droit du mur extérieur, ont aussi un tympan ajouré de la même manière "

xiv.

Carlos Alberto Ferreira de Almeida - Arquitectura Românica de Entre o Douro e Minho - Vol. II, Dissertação de Doutoramento em História da Arte apresentada à Faculdade de Letras da universidade do Porto, 1978, p. 141.

xv. Mosteiro de Santa Maria das Júnias - Notas para o estudo da sua evolução arquitectónica, in Revista da Faculdade de Letras da Universidade do Porto, II série, vol. 11, Porto, 1994, p. 420

xvi.

Parece-me incorrecta a afirmação de Maur Cocheril no Routier des Abbayes Cisterciennes du Portugal: "le cimetière - dont les piliers carrés du portail d'entrée sont surmontés de deux animaux couchés, grossièrement travaillés.". Os animais estão claramente em pé, não tenho notícia de alterações ao nível do muro do cemitério e o "grosseiramente trabalhados" parece-me discutível. xvii. Segundo Carlos Alberto Ferreira de Almeida - Arquitectura Românica de Entre o Douro e Minho Vol. II, Dissertação de Doutoramento em História da Arte apresentada à Faculdade de Letras da universidade do Porto, 1978, p. 235, a actual cornija é renascentista: Talvez, por esta razão, a sua cornija românica tenha desaparecido, se é que chegou a ser feita. A que se vê é renascentista.

xviii. Carlos Alberto Ferreira de Almeida - Arquitectura Românica de Entre o Douro e Minho - Vol. II, Dissertação de Doutoramento em História da Arte apresentada à Faculdade de Letras da universidade do Porto, 1978, p. 235, fala mesmo em substituição: Por isso as suas portas são muito baixas, embora as laterais já não tenham os dinteis que primitivamente apresentavam.

xix. Mário Barroca - Mosteiro de Santa Maria das Júnias - Notas para o estudo da sua evolução arquitectónica, in Revista da Faculdade de Letras da Universidade do Porto, II série, vol. 11, Porto, 1994, pp. 419-420.

xx. Maur Coucheril, - Routier des Abbayes Cisterciennes du Portugal - Paris: Fondation Calouste Gulbenkian, Centre Cultural Portugais, 1986, p.68.

xxi. Segundo informações da DGMN estas escadas terão sido construídas, nos finais do século XIX, durante um período em que o mosteiro foi utilizado para fins civis.

xxii.

Mosteiro de Santa Maria das Júnias - Notas para o estudo da sua evolução arquitectónica, in Revista da Faculdade de Letras da Universidade do Porto, II série, vol. 11, Porto, 1994, p. 424.

xxiii.

Maur Cocheril, no Routier des Abbayes Cisterciennes du Portugal, fala de uma pequena ponte feita de pedras planas: “On le traverse sur une petit pont fait de pierres plates..". Há de facto, à entrada da aldeia, uma ponte com essas características; actualmente, junto ao mosteiro a ponte é de madeira. 


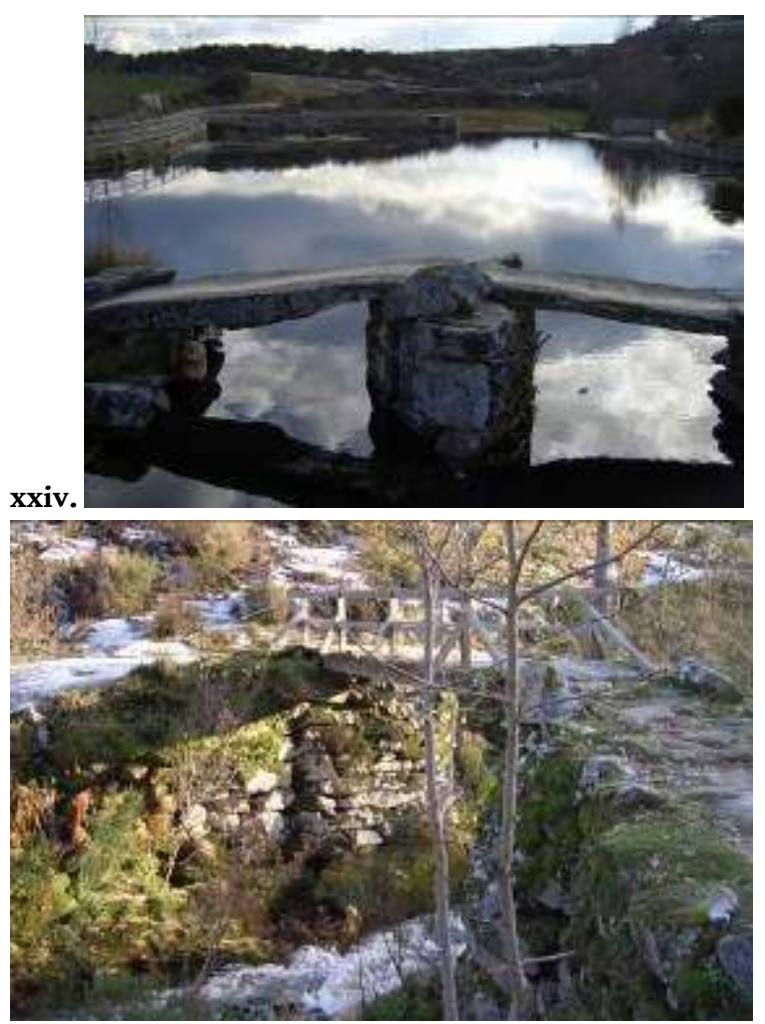

Ponte em lajes de pedra à entrada da aldeia de Pitões das Júnias (em cima) e ponte de madeira junto ao Mosteiro (em baixo)

Tratado de Arquitectura de Vitrúvio, Livro IV, capítulo IX. Os princípios construtivos dos dez livros de Vitrúvio não eram desconhecidos dos cistercienses, que não só os conheciam como também os aplicavam; como atesta a descoberta das ânforas, feita por Camille de Montalivet, em 1997 na Igreja de Loc Dieu, vindo assim comprovar o conhecimento que os cistercienses tinham da acústica de Vitrúvio (Livro V, capítulo V).

xxv. José Carlos Valle Pérez, - La Arquitectura Cisterciense en Galicia - vol. II, Coruña: Fundación Pedro Barrié de la Maza, 1986, p. 57.

xxvi. $O$ piso térreo apresenta actualmente seis divisões devido a uma parede levantada, nos finais do século XIX, segundo informações da DGMN, na sala do capítulo.

xxvii. Ernesto Veiga de Oliveira e Fernando Galhano - Arquitectura tradicional portuguesa, Lisboa: Publicações D. Quixote, 1992, pp. 111-130.

xxviii. Mário Barroca - Mosteiro de Santa Maria das Júnias - Notas para o estudo da sua evolução arquitectónica, in Revista da Faculdade de Letras da Universidade do Porto, II série, vol. 11, Porto, 1994, p. 428.

xxix. Mário Barroca - Mosteiro de Santa Maria das Júnias - Notas para o estudo da sua evolução arquitectónica, in Revista da Faculdade de Letras da Universidade do Porto, II série, vol. 11, Porto, 1994, p. 427.

\section{AUTOR}

\section{DELMIRA ESPADA}

IEM 